\title{
Risk assessment and the adsorptive removal of some pesticides from synthetic wastewater: a review
}

\author{
Zaharaddeen N. Garba ${ }^{1 *}$, Amina K. Abdullahi ${ }^{1}$, Abdurrashid Haruna ${ }^{1}$ and Sa'adatu A. Gana ${ }^{2}$
}

\begin{abstract}
Background: The need for environmental protection and remediation processes has been an increasing global concern. Pesticides are used as biological agents, disinfectants, antimicrobials, and also in a mixture of some chemical substances. Their modes of application are through selective dispensing and attenuation processes which act upon any pest that compete with the production, processing, and storage of foods and also in agricultural commodes. The pests might comprise weeds, insects, birds, fish, and microbes.

Main body: Pesticides are commonly found in water surface, landfill leachate, ground water, and wastewater as pollutant. An overview of recently studied adsorption processes for the pesticide elimination from polluted water has been reported in this study utilizing activated carbon, clay materials, biomass materials, metal organic frame work, graphene, and carbon-based materials as well as agricultural wastes as adsorbents. The risk assessment and cost analysis of adsorbents were also provided.

Conclusion: Evidences from literature recommend modified adsorbent and composite materials to have a prospective use in pesticide removal from wastewater. The adsorption data obtained fitted into different isotherm and kinetic models and also the thermodynamic aspect have been discussed.
\end{abstract}

Keywords: Pesticides, Adsorptive removal, Synthetic wastewater, Adsorbents, Wastewater treatment, Risk assessment

\section{Background}

Water is very crucial to life and the survival of living organisms in the environment, playing a vital role as well in agricultural productivity [1]. In a quest to overcoming the increasing global water demand, reuse and recycling of wastewater were given a considerable attention. Varieties of pollutants from organic and inorganic substances contaminate the wastewater. Inadequate supply of contaminant-free water continues to be an environmental challenge bedeviling several countries [2-9].

Modern farming is almost impossible without the application of pesticides. Organochlorine pesticides (OCPs) were revealed among the most tenacious class

\footnotetext{
* Correspondence: dinigetso2000@gmail.com

${ }^{1}$ Department of Chemistry, Ahmadu Bello University, Zaria, Nigeria

Full list of author information is available at the end of the article
}

of organic pollutants which were initially limited or freezed out worldwide in the 1980s [10, 11]. Contrary to the OCPs, there are some pesticides (synthetic pyrethroids and organophosphates) that are usually categorized as being relatively less persistent and hence widely employed in pest control [12, 13]. However, to some aquatic organisms such as fish, invertebrates, and mollusks, the increased application of synthetic pyrethroids (SPs) and organophosphorus pesticides (OPPs) presents very high chronic and acute toxicity to them [14-16]. Putting all these factors into consideration, water safety cannot be guaranteed with the presence of pesticides [13, 17]. Literature reports also suggested rivers neighboring agricultural catchments to be bedeviled with serious challenges due to the rapid growing applications of pesticides [18, 19].

\section{Springer Open}

(๑) The Author(s). 2021 Open Access This article is licensed under a Creative Commons Attribution 4.0 International License, which permits use, sharing, adaptation, distribution and reproduction in any medium or format, as long as you give appropriate credit to the original author(s) and the source, provide a link to the Creative Commons licence, and indicate if changes were made. The images or other third party material in this article are included in the article's Creative Commons licence, unless indicated otherwise in a credit line to the material. If material is not included in the article's Creative Commons licence and your intended use is not permitted by statutory regulation or exceeds the permitted use, you will need to obtain permission directly from the copyright holder. To view a copy of this licence, visit http://creativecommons.org/licenses/by/4.0/. 
The crucial question now is why pesticides? Our simple response is pesticides are very popular compounds; their residues may exist in water, soil, and sediments. Their toxicity and persistence make their elimination from wastewater crucial. The next question is, why adsorption process could be an effective method for removing them? We hope to answer the question considering that adsorption phenomenon as is one of the fastest and simplest applications used in separation. It has merit in wastewater treatment based on fast kinetics, simplicity in design, and high removal capacity when compared with other methods.

The thought of this review was considered after a thorough literature search on how adsorption process was utilized the pesticides removal from wastewater for over 25 years. During our survey, we came across some well-written review articles by other researchers on pesticides [20-29] but emphasis on adsorption as the most suitable process for decontaminating wastewater polluted by pesticides were not made. The literature information consulted for this review were mostly derived from science direct database. The words "pesticide adsorption" were used for the search. An observation was made on the increasing numerical pattern of the published articles on pesticide adsorption (Fig. 1) having the lowest number (524) in 1997. In 2019, 3478 were published while additional 2194 were published from January to April 2020. Review that covers recent research information on using different adsorptive techniques for pesticide adsorption was not comprehensively reported despite the high quantity of published articles. With that into consideration, we provided the most recent information on the progress made for using activated carbon and as well as other alternative adsorbents such as clay materials, biomass materials, agricultural wastes, carbon and graphene-based adsorbents, metal organic frameworks, zeolites, nano composites, and polymeric materials that were applied in pesticide adsorption, forming the primary objective of this review article.

\subsection{Pesticides and their risk assessment}

Crop protection is the most popular way where pesticides are utilized in agriculture with reported global increase in their production and usage [30,31]. Various researchers reported regular monitoring and effects of pesticides in the European waters with agricultural runoff and/or leaching as the simplest way pesticides could enter into surface waters [32-34], thereby making the ecosystem and/or living organisms vulnerable to various health hazards. Several factors were revealed to play a key role in making these pesticides dangerous for drinking water. One of the factors reported was applying the pesticides in a large scale and/or used for contrasting purposes. The soil being vulnerable to the pesticides leaching in to groundwater was another reported factor. Other relevant risk drivers include specific properties such as the toxicity, mobility, and persistence [35]. Some pesticides were classified as persistent and mobile organic compounds (PMOCs) well known for the easy bypassing of wastewater treatment processes, and thus threatening the drinking water quality $[36,37]$. How pesticides occur and their concentrations in drinking water were the basis used in prioritizing them as shown in Table 1.

Pesticides were classified as high priority ones when detected in water for drinking purpose, especially when their concentration in the water source exceed $0.1 \mu \mathrm{g} / \mathrm{L}$ standard. This standard is based on a decree from EU Water Framework (Table 1). Meanwhile, if the concentration of pesticides and their metabolites are greater than $10 \%$ limits of water quality standard from drinking

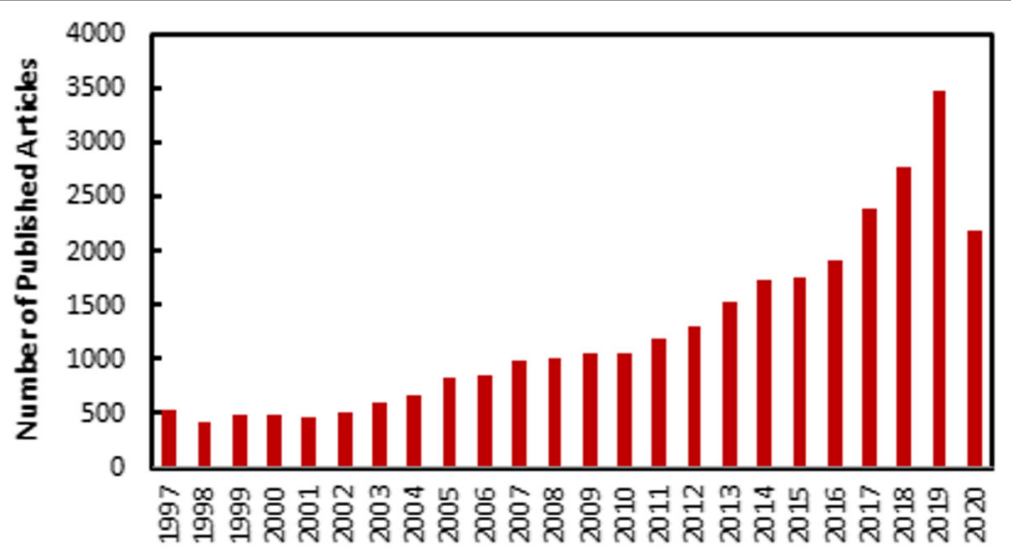

Year of Publication

Fig. 1 The number of available annual scientific publications from 1997 till 2020. The term "pesticide adsorption" was adopted as a searching term. Data were obtained from Scopus search system on 6th April, 2020 
Table 1 Risk classification of pesticides [30]

\begin{tabular}{ll}
\hline Priority class & Criteria \\
\hline High priority & Pesticides or relevant metabolites present in produced drinking water \\
Priority & $\begin{array}{l}\text { Pesticides or relevant metabolites present in drinking water sources }>0.1 \mathrm{mg} / \mathrm{L} \text { (for } 90 \text { th } \% \text { of all data }>\mathrm{LOQ} \text { ) } \\
\text { Non-relevant metabolites present in drinking water sources }>1 \mathrm{mg} / \mathrm{L} \text { (for } 90 \text { th } \% \text { of all data }>\mathrm{LOQ}\end{array}$ \\
$\begin{array}{l}\text { Potential } \\
\text { priority }\end{array}$ & $\begin{array}{l}\text { Pesticides or relevant metabolites present drinking water sources }>0.1<0.1 \mathrm{mg} / \mathrm{L} \text { (for } 90 \text { th } \% \text { of all data }>\mathrm{LOQ} \text { ) } \\
\text { Low priority }\end{array}$ \\
& $\begin{array}{l}\text { Not detected pesticides and or relevant metabolites and pesticides or relevant metabolites present drinking water sources do not } \\
\text { exceed } 0.01 \mathrm{mg} / \mathrm{L}\end{array}$ \\
\hline
\end{tabular}

water sources, then they are considered as a potential priority.

\section{Main text}

\subsection{Pesticide removal by adsorption}

There is no dearth of reports on adsorption as the best method in getting rid of pesticides from synthetic wastewater, with Table 2 summarizing how various adsorbents were applied for the removal of these pesticide contaminants.

\subsection{Activated carbon}

The popularity of activated carbon as a very useful material in catalytic and adsorption applications is well known due to being highly porous with large surface area [69-72]. To date, there is no adsorbent material that surpass activated carbon [73-76] popularly employed in treating wastewater [68, 77-83], oil and gas industry [84], in food processing [85], remediation of air pollution [86], and pharmaceuticals [87, 88]. Activated carbon usually appears either in granular or powdered form.

Coconut shell activated carbon was employed by Ignatowicz [39] in studying the adsorption isotherms of hexachlorocyclohexane $(\mathrm{HCH})$ at constant temperature, thereby revealing Langmuir, Freundlich, and Jovanovic to best describe the equilibrium generated data. The nature of isotherm shape hinted at monolayer adsorption of $\mathrm{HCH}$, signaling a negligible competition between water and the $\mathrm{HCH}$ pesticide molecules in occupying the adsorption surface sites. In another development, Ayranci and Hoda [89] revealed how they succeeded in removing four pesticides such as diuron, ametryn, dinoseb, and aldicarb, by adsorption using high surface area carbon-cloth.

The whole process was completed in 125 min with the adsorption rate constants for the two models in an increasing order of aldicarb < diuron < ametryn < dinoseb.

Date seed activated carbon (DSAC) was reported as an efficacious adsorbent by Salman and co-workers [40] for the elimination of two pesticides (carbofuran and bentazon). Pseudo-second-order model explained the kinetic of the adsorption processes for both adsorbates which also suggested that the adsorption rate to be less reliable on the solution concentration but more dependent on the adsorption sites availability. Higher adsorption capacity was revealed in favor of carbofuran than bentazon with ethanol used as solvent in order to desorb the spent DSAC for 3 cycles, giving rise to percentage desorption 82.2 and $84.1 \%$ for carbofuran and bentazon respectively [40]. The obtained values for DSAC adsorption capacity for removing the two pesticides affirmed the efficiency of date seed as a potent precursor in the activated carbon production on for the treatment of wastewater contaminated with bentazon and carbofuran.

The waste fiber of hemp (Cannabis sativa) was also utilized by Vukcevic et al. [49] for the activated carbon preparation that show large specific surface area of 2192 $\mathrm{m}^{2} / \mathrm{g}$. $\mathrm{KOH}$ was the chemical activating agent employed in the process which gradually took place through the three apparent phases of hydrogen evolution. During the activation process, a major $\mathrm{CO}$ and $\mathrm{H}_{2}$ evolution occurred as the $\mathrm{KOH} /$ carbonized material ratio increased and a shift in temperature was observed. Based on good correlation between porosity development as well as the $\mathrm{CO}$ and $\mathrm{H}_{2}$ evolution, the process of activation took place at high temperature thereby producing a welldeveloped high surfaced area activated carbon. They reported the adsorbent produced by carbonization and subsequent activation of the waste hemp fibers with the ratio of 2:1 for $\mathrm{KOH} /$ carbonized material at $900{ }^{\circ} \mathrm{C}$ is to have the highest pesticide removal efficiency.

In a recent development, the successful preparation of mesoporous activated carbon from starch (ACS), capable of removing more than 10 pesticides from contaminated water was reported [42]. Upon comparison with other adsorbents, the ACS produced by Suo and co-workers [42] show that all the pesticide adsorption rates were greater than those obtained using graphitized carbon black (GCB) and commercial activated carbon.

\subsection{Agricultural wastes}

Agricultural wastes that contain lignin, cellulose, and hemicelluloses are generally termed as lignocellulosic materials, mainly characterized by a large number of active groups (hydroxyl, amino, methyl, carbonyl and carboxyl). The utilization of these waste materials remained a global problem, which prompted many researchers to 
Table 2 Characteristic properties of different adsorbents employed for the adsorption of pesticides

\begin{tabular}{|c|c|c|c|c|c|c|c|}
\hline Adsorbents & Pesticides & Surface morphology & $\begin{array}{l}\text { Surface } \\
\text { area } \\
\left(\mathrm{m}^{2} / \mathrm{g}\right)\end{array}$ & $\begin{array}{l}\text { Total } \\
\text { pore } \\
\text { volume } \\
\left(\mathrm{cm}^{3} / \mathrm{g}\right)\end{array}$ & $\begin{array}{l}\text { Pore size } \\
\text { diameter } \\
(\mathrm{nm})\end{array}$ & $\mathrm{pH}_{\mathrm{pzc}}$ & References \\
\hline $\begin{array}{l}\text { Granular activated } \\
\text { carbon (GAC F300) }\end{array}$ & $\begin{array}{l}\text { Carbofuran and 2,4- } \\
\text { dichlorophenoxyacetic acid }\end{array}$ & Coarse rough and porous surface & 731.48 & 0.45 & - & - & {$[38]$} \\
\hline $\begin{array}{l}\text { Coconut shell based } \\
\text { Activated carbon np-5 }\end{array}$ & Hexachlorocyclohexane & $\begin{array}{l}\text { Well-developed pores on the } \\
\text { surface }\end{array}$ & 1840 & 0.90 & - & - & [39] \\
\hline $\begin{array}{l}\text { Date seed activated } \\
\text { carbon }\end{array}$ & Bentazon and carbofuran & - . & 880.18 & 0.46 & 2.16 & - & {$[40]$} \\
\hline $\begin{array}{l}\text { Activated carbon from } \\
\text { palm oil fronds }\end{array}$ & $\begin{array}{l}\text { Bentazon, carbofuran and 2,4- } \\
\text { dichlorophenoxyacetic acid }\end{array}$ & Well-developed porous surface & 1237.13 & 0.67 & 2.16 & & [41] \\
\hline $\begin{array}{l}\text { Mesoporous activated } \\
\text { carbon from starch } \\
\text { (ACS) }\end{array}$ & $\begin{array}{l}\text { Atrazine, pymetrozine, } \\
\text { acetamiprid, diuron, thiacloprid, } \\
\text { imazalil, difenoconazole, } \\
\text { azoxystrobin, pyraclostrobin, } \\
\text { trifloxystrobin, and } \\
\text { chlorantraniliprole }\end{array}$ & $\begin{array}{l}\text { The ACS surface was full of } \\
\text { micropores and mesoporous }\end{array}$ & - & - & - & - & {$[42]$} \\
\hline $\begin{array}{l}\text { Waste rubber tire } \\
\text { activated carbon }\end{array}$ & $\begin{array}{l}\text { Methoxychlor, methyl parathion } \\
\text { and atrazine }\end{array}$ & $\begin{array}{l}\text { Chemically treated sorbent is } \\
\text { highly porous as compared to the } \\
\text { untreated adsorbent }\end{array}$ & 981 & 1.51 & 3.12 & - & [43] \\
\hline Activated carbon F300 & Phenoxyacid pesticide & - & 762 & 0.46 & $\sim 0.52$ & $\tilde{9} .80$ & [44] \\
\hline $\begin{array}{l}\text { Olive kernels activated } \\
\text { carbon }\end{array}$ & Bromopropylate (BP) & $\begin{array}{l}\text { Cross-interconnected pores } \\
\text { spongy-like, surface }\end{array}$ & 600 & 0.30 & - & - & [45] \\
\hline $\begin{array}{l}\text { Corn cobs activated } \\
\text { carbon }\end{array}$ & Bromopropylate (BP) & $\begin{array}{l}\text { Cross-interconnected pores } \\
\text { spongy-like, surface }\end{array}$ & 630 & 0.34 & - & - & [45] \\
\hline $\begin{array}{l}\text { Soya stalks activated } \\
\text { carbon }\end{array}$ & Bromopropylate (BP) & $\begin{array}{l}\text { Fibrous-like structure in nature } \\
\text { with long ridges, resembling a } \\
\text { series of parallel lines }\end{array}$ & 570 & 0.31 & - & - & [45] \\
\hline $\begin{array}{l}\text { Rapeseed stalks } \\
\text { activated carbon }\end{array}$ & Bromopropylate (BP) & $\begin{array}{l}\text { Fibrous-like structure in nature } \\
\text { with long ridges, resembling a } \\
\text { series of parallel lines }\end{array}$ & 490 & 0.28 & - & - & [45] \\
\hline $\begin{array}{l}\text { Activated carbon } \\
\text { NORIT_GL } 50\end{array}$ & Bromopropylate (BP) & Rough and porous surface & 650 & - & - & - & {$[46]$} \\
\hline Activated carbon F400 & Bromopropylate (BP) & Coarse and porous surface & 827 & 0.52 & - & - & [47] \\
\hline $\begin{array}{l}\text { Mesoporous activated } \\
\text { carbon from coconut } \\
\text { frond }\end{array}$ & Carbofuran & $\begin{array}{l}\text { Considerable number of pores } \\
\text { with homogeneous circle shapes } \\
\text { with different sizes of apertures } \\
\text { distributed on the surface }\end{array}$ & 483.64 & 0.21 & 2.97 & 5.80 & [48] \\
\hline $\begin{array}{l}\text { Activated carbon from } \\
\text { waste hemp }\end{array}$ & $\begin{array}{l}\text { Acetamiprid, dimethoate, } \\
\text { nicosulfuron, carbofuran and } \\
\text { atrazine }\end{array}$ & $\begin{array}{l}\text { Fibrous structure with uniform } \\
\text { nanostructured network }\end{array}$ & 2192 & 1.06 & 1.79 & - & [49] \\
\hline $\begin{array}{l}\text { Coconut shell } \\
\text { activated carbon }\end{array}$ & Malathion & $\begin{array}{l}\text { Irregular structure and porous } \\
\text { surface with the external pore size } \\
\text { varies from } 1.14 \text { to } 2.35 \mu \mathrm{m}\end{array}$ & 850 & 281 & 2.18 & & {$[50]$} \\
\hline $\begin{array}{l}\text { Palm shell activated } \\
\text { carbon }\end{array}$ & Malathion & $\begin{array}{l}\text { Irregular structure and porous } \\
\text { surface with the external pore size } \\
\text { varies from } 0.15 \text { to } 1.09 \mu \mathrm{m}\end{array}$ & 788 & 261 & 1.73 & & {$[50]$} \\
\hline $\begin{array}{l}\mathrm{NH}_{4} \mathrm{Cl} \text {-induced } \\
\text { activated carbon }\end{array}$ & Diazinon & - & 1029 & 236.40 & 2.46 & 6.6 & [51] \\
\hline $\begin{array}{l}\text { Graphitic carbon } \\
\text { nanostructures from } \\
\text { filter paper }\end{array}$ & 2,4-dichlorophenoxyacetic acid & Thin foam-like porous structure & 182.40 & 0.31 & 6.88 & - & [52] \\
\hline $\begin{array}{l}\text { Graphitic carbon } \\
\text { nanostructures from } \\
\text { cotton }\end{array}$ & 2,4-dichlorophenoxyacetic acid & $\begin{array}{l}\text { Flat carbon sheets with very thin } \\
\text { thickness. }\end{array}$ & 27.40 & 0.03 & 4.99 & - & {$[52]$} \\
\hline Phenyl-modified & Avermectin, imidacloprid, & Some ordered mesoporous & 446.50 & 0.32 & 2.80 & - & [53] \\
\hline
\end{tabular}


Table 2 Characteristic properties of different adsorbents employed for the adsorption of pesticides (Continued)

\begin{tabular}{|c|c|c|c|c|c|c|c|}
\hline Adsorbents & Pesticides & Surface morphology & $\begin{array}{l}\text { Surface } \\
\text { area } \\
\left(\mathrm{m}^{2} / \mathrm{g}\right)\end{array}$ & $\begin{array}{l}\text { Total } \\
\text { pore } \\
\text { volume } \\
\left(\mathrm{cm}^{3} / \mathrm{g}\right)\end{array}$ & $\begin{array}{l}\text { Pore size } \\
\text { diameter } \\
(\mathrm{nm})\end{array}$ & $\mathrm{pH}_{\mathrm{pzc}}$ & References \\
\hline $\begin{array}{l}\text { magnetic graphene/ } \\
\text { mesoporous silica }\end{array}$ & $\begin{array}{l}\text { pyridaben, dichlorvos, } \\
\text { acetamiprid, dursban, } \\
\text { isocarbophos, and phoxim }\end{array}$ & $\begin{array}{l}\text { structure were overlaid with little } \\
\text { aggregation or multilayer } \\
\text { accumulation of the magnetic } \\
\text { graphene sheets }\end{array}$ & & & & & \\
\hline $\begin{array}{l}\text { Mesoporous carbon } \\
\text { from a biopolymer } \\
\text { and clay }\end{array}$ & Dicamba Pestanal & $\begin{array}{l}\text { Oriented cleavage planes on the } \\
\text { surface }\end{array}$ & 876 & 0.04 & 3.40 & 4.10 & [54] \\
\hline $\begin{array}{l}\text { Graphene oxide-based } \\
\text { silica-coated magnetic } \\
\text { nanoparticles function- } \\
\text { alized with 2- } \\
\text { phenylethylamine }\end{array}$ & $\begin{array}{l}\text { Chlorpyrifos, parathion, and } \\
\text { malathion }\end{array}$ & $\begin{array}{l}\text { Spherical in shape and } \\
\text { agglomerated }\end{array}$ & 133 & 0.48 & 17.50 & - & [55] \\
\hline $\begin{array}{l}\text { SAz-1 montmorillonite } \\
\text { with the cationic } \\
\text { polymer } \\
\text { hexadimethrine }\end{array}$ & $\begin{array}{l}\text { Fluome-turon, diuron, } \\
\text { terbuthylazine, simazine, } \\
\text { mecoprop, MCPA, andclopyralid }\end{array}$ & $\begin{array}{l}\text { Less aggregated morphology and } \\
\text { flat plates }\end{array}$ & 51 & - & - & - & {$[56]$} \\
\hline $\begin{array}{l}\text { Alkaline modified } \\
\text { commercial kaolin }\end{array}$ & Methomyl & $\begin{array}{l}\text { Aggregated particles with an } \\
\text { average diameter of } 400 \mathrm{~nm}\end{array}$ & 8.51 & 0.0005 & 18.39 & & [57] \\
\hline $\begin{array}{l}\text { Phosphate-modified } \\
\text { kaolin }\end{array}$ & Methomyl & Irregular curved flakes & 18.79 & 0.002 & 12.26 & & {$[57]$} \\
\hline \multirow[t]{2}{*}{$\begin{array}{l}\text { Layered double } \\
\text { hydroxides }\end{array}$} & Alachlor and metolachlor & $\begin{array}{l}\text { Thin plate-like crystal with an ir- } \\
\text { regular shape and size }<10 \mu \mathrm{m}\end{array}$ & - & - & - & - & {$[58]$} \\
\hline & & $\begin{array}{l}\text { Presence of lamellar and layered } \\
\text { particles distributed around the } \\
\text { surface, dominated by the flaked } \\
\text { aggregates and curling edges } \\
\text { with fluffy appearance }\end{array}$ & 164.79 & 0.27 & 6.57 & 6.75 & [59] \\
\hline $\begin{array}{l}\text { Magnetic copper- } \\
\text { based metal organic } \\
\text { framework }\end{array}$ & $\begin{array}{l}\text { Thiamethoxam, imidacloprid, } \\
\text { acetamiprid, nitenpyram, } \\
\text { dinotefuran, clothianidin, and } \\
\text { thiacloprid }\end{array}$ & $\begin{array}{l}\text { Highly porous block-shaped } \\
\text { structure. }\end{array}$ & 250.33 & 0.83 & - & - & {$[60]$} \\
\hline $\begin{array}{l}\text { Zr-metal organic } \\
\text { framework } \\
\text { functionalized } \\
\text { magneticgraphene } \\
\text { nanocomposites }\end{array}$ & $\begin{array}{l}\text { Triflurain, atrazine, } \\
\text { methylparathion, pirimiphos } \\
\text { methyl, parathion, penconazole, } \\
\text { procymidone, bfienthrin, and } \\
\text { cyhalothrin }\end{array}$ & $\begin{array}{l}\text { Even distribution of magnetic } \\
\text { particles on the surface of } \\
\text { graphene, some of them are } \\
\text { wrapped in MOF with both of } \\
\text { them having good core-shell } \\
\text { structure, the thickness of mate- } \\
\text { rials was increased significantly } \\
\text { after being modified with Zr-MOF }\end{array}$ & 178.1 & - & - & - & [61] \\
\hline $\begin{array}{l}\text { Multi-walled carbon } \\
\text { nanotubes }\end{array}$ & Diazinon & $\begin{array}{l}\text { Porous tubular structures of multi- } \\
\text { walled carbon nanotubes }\end{array}$ & 370 & - & - & $3-5$ & {$[62]$} \\
\hline $\begin{array}{l}\text { modified chitosan } \\
\text { materials }\end{array}$ & Pentachlorophenol & $\begin{array}{l}\text { Non homogenous and quite } \\
\text { rough surface }\end{array}$ & $\begin{array}{l}2.43- \\
0.37\end{array}$ & $\begin{array}{l}0.17-1.7 \\
\times 10^{-3}\end{array}$ & - & $4-7.7$ & {$[63]$} \\
\hline $\mathrm{LaFe}_{0.9} \mathrm{CO}_{0.1} \mathrm{O}_{3}$ & Vitavax & $\begin{array}{l}\text { Rough and nearly fully covered } \\
\text { with the particles grown on it and } \\
\text { the particle size distribution seems } \\
\text { to be in the range } 50-400 \mathrm{~nm}\end{array}$ & 51.2 & - & - & - & [64] \\
\hline $\mathrm{LaFe}_{0.1} \mathrm{CO}_{0.9} \mathrm{O}_{3}$ & Vitavax & $\begin{array}{l}\text { Nearly spherical with } \\
\text { approximately uniform particle } \\
\text { size and their distribution is } \\
\text { ranging between } 30 \text { and } 60 \mathrm{~nm} \\
\text { with the average diameter of } \\
\text { about } 40 \mathrm{~nm} \text {. }\end{array}$ & 42.8 & - & - & - & [64] \\
\hline $\begin{array}{l}\text { Pig manure-derived } \\
\text { biochars }\end{array}$ & Carbaryl and atrazine & $\begin{array}{l}\text { Bulk aromaticity of the biochar } \\
\text { increased and polarity decreased } \\
\text { with charring temperature }\end{array}$ & 218.10 & 0.32 & 57.80 & 6.40 & {$[65]$} \\
\hline Nanocrystalline & Diazinon and fenitrothion & Rough and scratchy surface with & 250 & - & 7 & - & [66] \\
\hline
\end{tabular}


Table 2 Characteristic properties of different adsorbents employed for the adsorption of pesticides (Continued)

\begin{tabular}{|c|c|c|c|c|c|c|c|}
\hline Adsorbents & Pesticides & Surface morphology & $\begin{array}{l}\text { Surface } \\
\text { area } \\
\left(\mathrm{m}^{2} / \mathrm{g}\right)\end{array}$ & $\begin{array}{l}\text { Total } \\
\text { pore } \\
\text { volume } \\
\left(\mathrm{cm}^{3} / \mathrm{g}\right)\end{array}$ & $\begin{array}{l}\text { Pore size } \\
\text { diameter } \\
(\mathrm{nm})\end{array}$ & $\mathrm{pH}_{\mathrm{pzc}}$ & References \\
\hline magnesium oxides & & $\begin{array}{l}\text { the particle size of } 6 \text { obtained } \\
\text { from TEM image }\end{array}$ & & & & & \\
\hline $\begin{array}{l}\text { Algerian palygorskite } \\
\text { modified with } \\
\text { magnetic iron with } \\
\text { hydrothermal } \\
\text { treatment }\left(\mathrm{FeO} \mathrm{Pal}_{1}\right)\end{array}$ & Linuron & $\begin{array}{l}\text { Iron oxide particle size varies } \\
\text { between } 7 \text { and } 15 \mathrm{~nm} \text {, with a } \\
\text { heterogeneous distribution of } \\
\text { spherical particles without obvious } \\
\text { aggregation and dispersed onto } \\
\text { the palygorskite needles' surface }\end{array}$ & - & - & - & - & [67] \\
\hline $\begin{array}{l}\text { Algerian palygorskite } \\
\text { modified with } \\
\text { magnetic iron without } \\
\text { hydrothermal } \\
\text { treatment }\left(\mathrm{FeO} \mathrm{Pal}_{2}\right)\end{array}$ & Linuron & $\begin{array}{l}\text { Iron oxide particles show square } \\
\text { and/or hexagonal outlines and } \\
\text { sizes from } 30 \text { to } 50 \mathrm{~nm}\end{array}$ & - & - & - & - & [67] \\
\hline $\begin{array}{l}\text { Copper modified } \\
\text { microcrystalline } \\
\text { cellulose }\end{array}$ & Prometryn & $\begin{array}{l}\text { Typical features of cellulose fibers } \\
\text { informed by the dispersed netting } \\
\text { lines and natural piral twists with } \\
\text { some } \mathrm{Cu}^{2+} \text { particles dispersed on } \\
\text { the surface }\end{array}$ & 6.06 & 0.01 & 11.52 & 11.30 & {$[68]$} \\
\hline
\end{tabular}

come up with various ways of harnessing these agricultural byproducts including their utilization as adsorbents for wastewater treatment. Complexation, hydrogen bonding, and ion exchange were the major adsorption mechanisms associated with agricultural solid wastes and their composites in the process of adsorbing organic compounds. Watermelon peels were treated both chemically and thermally by Memon et al. [90] to remove methyl parathion (MP) pesticide from synthetic wastewater by adsorption. The results revealed the treatments to be very effective at low $\mathrm{pH}$. Mechanism of the MP adsorption at acidic $\mathrm{pH}$ hinted at attractive forces playing a big role by enhancing the interaction between the adsorbate an adsorbent binding sites especially since the adsorbent surface was surrounded by hydronium ions with methanol being established as the best solvent in aiding desorption of the MP pesticide from the adsorbent surface.

Cobas and co-workers evaluated the potentials of a cheap biosorbent (chestnut shells) for the removal of thiamethoxam, pirimicarb, acetamiprid, and imidacloprid pesticides; the reports described the applicability of the biosorbent in eliminating the chosen pesticides [91]. The adsorption processes with respect to thiamethoxam, acetamiprid, and imidacloprid were best explained by pseudo-second-order and Freundlich isotherm kinetic models. A column adsorption system assay was used to demonstrate the suitable performance of the biosorbent (chestnut shells) working on continuous mode.

A new approach was taken by Aia et al. when they characterized the physical properties and chemical composition of mulch residues after exposing them to microbial decomposition [92]. From their results, they were able to establish a complementary data which should enable the readers to fully understand how both ionic and non-ionic pesticides were adsorbed as well as desorbed on the decomposed maize residues. Based on the provided information, compositional data analysis (CoDa) approach was employed in building a predictive model which utilized the sorption coefficient $K_{\text {oc. }}$ Though there were different results based on pesticide type, the pesticide sorption properties were greatly altered. This happens during decomposition of the crop residue due to changes in its chemical composition. For the non-ionic molecules such as S-metolachlor and epoxiconazole, their adsorption capacities were enhanced after decomposition upon comparison with glyphosate though glyphosate desorbed more readily from decomposed residues. Based on that, the non-ionic pesticides mobility was differently controlled by changes of crop residues pattern during decomposition when compared to ionic compounds of glyphosate. It is of paramount importance that the decomposition state of mulch be given high regard when considering models in predicting the pesticide behavior agricultural system conservation.

\subsection{Biomass}

Biomasses are very popular in studying the adsorptive removal of pesticides. Some mechanisms of biomass and biomass modified used in the control include mainly the ion exchange, surface adsorption, chelation, and complexation [93-95]. Wastewater contaminants in minute quantities can be removed effectively by using the biosorption method. Some of the common biomass employed for adsorption studies are algae, fungi, and bacteria. 
The valorization of Pleurotusmutilus fungal biomass was reported by Behloul et al. for metribuzin pesticide biosorption [96]. Two important parts were reported in the study; physical pretreatment and the biomass characterization constituted the first part with the second part studying the various parameters (particle size, agitation, biosorbent content, temperature, $\mathrm{pH}$, and metribuzin concentration) that have a very high chance of influencing the biosorption capacity of metribuzin. A very convincing result was obtained for the adsorption with a very rapid adsorption rate after about $3 \mathrm{~h}$, before reaching the equilibrium. Particle size almost substantially interferes with the accumulation rate and the required time needed to reach adsorption equilibrium. Then $3.3 \mathrm{mg} / \mathrm{g}$ was determined as the optimum adsorption capacity value [96]. In a different work, immobilization of Aspergillus laccase was supported by utilizing peanut shell sand wheat straw. The laccasecatalyzed degradation of nine pesticide (prochloraz, isoproturon, penoxsulam, mefenacet, atrazine, prometryn, nitenpyram, bensulfuron-methyl, and pyrazosulfuronethyl) was improved upon employing redox mediator syringaldehyde [97]. The obtained results signaled successful pesticide adsorptions in soil and environmental wastewater samples. They reported the successful removal of over 65.9 and $54.5 \%$ of pesticides using wheat straw immobilized laccase and peanut shell immobilized laccase for 3 days. The dosage of immobilized laccase biosorbent used was $25 \mathrm{~g} / \mathrm{L}$. However, the treatment of soil contaminated with pesticide compounds was conducted using wheat straw immobilized laccase and peanut shell immobilized laccase within 7 days. The biosorbent dose was $50 \mathrm{~g} / \mathrm{kg}$ (soil). The maximum degradation rates were reported to range from 14.7 to 92.0 and 20.9 to $92.9 \%$ respectively. Hence, it was concluded that biosorption coupled with laccase degradation presents an effective way of pesticide removal from wastewater especially when the laccase is immobilized on biomass materials.

Generally, practical applications of biomass are limited by some derelictions which include the biomass low rate of adsorption rate due to the adsorption process very reliant on the $\mathrm{pH}$.

\subsection{Carbon and graphene-based adsorbents}

A study was conducted on magnetic and graphitic carbon nanostructures for the elimination of 2,4-D pesticide [52]. The magnetic nanoparticles prepared from filter paper $(\mathrm{GCN}-\mathrm{P})$ and cotton $(\mathrm{GCN}-\mathrm{C})$ were revealed to have higher BET surface area for GCN-P than GCN-C. The equilibrium data was best explained by the RedlichPeterson isotherm with Elovich and M-exponential models explaining the kinetic data for GCN-P and $\mathrm{GCN}-\mathrm{C}$ respectively, hinting at heterogeneous surface being provided by both adsorbents for the 2,4-D adsorption [52]. Magnetic property is another advantage credited to the nanostructures prepared from magnetic and graphitic carbon with the magnet favoring easy separation from the solution.

Fifteen different types of pesticides were used in contaminating water, the treatment was conducted using six various types of adsorbent which were treated and untreated rice straw biochar, corn stover biochar, and charcoal [98]. The researchers further studied the effects of some factors which include solution $\mathrm{pH}$, water/adsorbent ratio, and pesticide concentration in the rice straw biochar that was not treated. Greater total pore volumes and larger surface areas were observed for corn stover biochars and untreated rice straw upon comparison to untreated charcoal with phosphoric acid treatment strongly influencing the surface functional groups and aromatization with respect to all the treated adsorbents. A study by Wanjeri et al. [55] reported the potential of graphene oxide-based silica-coated magnetic nanoparticles $\left(\mathrm{Fe}_{3} \mathrm{O}_{4} @ \mathrm{SiO}_{2} @ \mathrm{GO}\right)$ functionalized with 2phenylethylamine (PEA) in the adsorption of some organophosphorus pesticides (OPPs) namely chlorpyrifos, parathion, and malathion [55]. The optimum adsorption conditions were reported to be $15 \mathrm{~min}$ contact time, 15 $\mathrm{mg}$ adsorbent dosage, and the solution concentration of $1 \mu \mathrm{g} / \mathrm{mL}$ with a negligible disparity in the $\mathrm{pH}$ condition, hinting at the suitability of using the material on various samples. The equilibrium and kinetic data of all the three pesticides were best described by the non-linear Sips and pseudo-second-order kinetic models respectively. After 10 cycles, there was a very low recovery of the OPPs from aqueous solution but after testing the adsorbent real wastewater samples from the Vaal River and Dam (South Africa), a recovery greater than 86.9 \% was reported. The results confirmed the efficiency of the synthesized $\mathrm{Fe}_{3} \mathrm{O}_{4} @ \mathrm{SiO}_{2} @ G O-P E A$ as a good adsorbent for the adsorption of pesticides.

\subsection{Clay adsorbents}

Other widely employed adsorbents applied to rid wastewater from varieties of pollutants such as pesticides are clay materials. An extensive adsorption-desorption study of endosulfan was reported on various Indian soils which are clayey soil (CL-lean clay with sand), red soil (GMsilty gravel with sand), sandy soil (SM-silty sand with gravel), and composted soil (PT-peat) based on the accepted standards set by ASTM (American Society for Testing and Materials) [99]. Their adsorption-desorption rate values were established to vary for alpha and beta endosulfan, relying on the type of soil used. The maximum specific adsorption capacity $\left(q_{\max }\right)$ values for the different soils varied from 0.1 to $0.45 \mathrm{mg} / \mathrm{g}$ for alpha endosulfan and 0.0942 to $0.2722 \mathrm{mg} / \mathrm{g}$ for beta endosulfan. 
The maximum adsorption follows the order clay soil $>$ composted soil $>$ red soil $>$ sand with functional groups effect more pronounced in clayey soil. There was a decreased endosulfan adsorption in clay soil at lower $\mathrm{pH}$ with higher desorption reported at both acidic and alkaline $\mathrm{pH}$ ranges when likened to neutral $\mathrm{pH}$. The results further indicated alpha endosulfan to be more mobile than beta endosulfan [99]. It is more advisable to immobilize endosulfan in clay soil with biological and/or chemical process more suited to the effective remediation of other soil types.

Another investigation revealed how two distinct organohydrotalcites (OHTs): one intercalated with dodecylsulfate (HT-DDS) and the other one with tetradecanedioate (HT-TDD) anions, prepared by the co precipitation method influenced the removal of non-ionic pesticide S-Metolachlor by adsorption [100]. The adsorption of S-Metolachlor pesticide was reported to be higher on the HT-TDD than HT-DDS, but lower desorption. Increase in temperature was also reported to enhance the adsorption of S-Metolachlor onto HT-TDD with the pesticide desorption process suggesting higher reversibility of S-Metolachlor adsorption from HT-DDS compared to HT-TDD. The results hinted at the possible role organohydrotalcites can play in removing $\mathrm{S}$ Metolachlor pesticide from polluted water. In another development, Rodríguez-Liébana and co-workers evaluated a total of nine natural clay samples from South of Spain and the role they may play in the retention of metalaxyl and fludioxonil (two popularly used non-ionic fungicides) [101]. Different granulometry and mineralogical composition, high Ca content, and medium-low cation exchange capacity as well as specific surface area and low organic carbon content $(\leq 0.8 \%)$ were reported for the various clay samples. The Freundlich and pseudo-second-order models best explained the equilibrium and kinetic data generated with respect to metalaxyl adsorption, with both Freundlich and Langmuir best suited to the fludioxonil. Electrostatic attractions played a greater role in explaining why there was a better retention of metalaxyl (a more polar fungicide) than fludioxonil.

A novel functional material was synthesized and characterized by Gámiz and co-workers where they employed a cationic polymer hexadimethrine (SAHEXAD) for the modification of SAz-1 montmorillonite which was compared with the more popular hexadecyl trimethyl ammonium-modified SAz-1 montmorronite (SA-HDTMA) [56]. Potential of the new nanocomposite in decontaminating wastewater from pesticides was explored with the characterization and adsorption experiments revealing the extent of pesticide adsorption to strongly rely on the structure and features of the surface of each organo-clay as well as the nature of the considered pesticide. High affinity for anionic pesticides was noticed to be stronger with respect to SA-HEXAD which was presumably stimulated by electrostatic attraction on positively charged ammonium groups of the polymer but not by direct interaction with the clay. However, hydrophobic interactions were revealed to have big influence on SA-HDTMA showing greater adsorption of both uncharged and anionic pesticides. The success of their work involved providing new information about the surface properties of a novel organic-inorganic nanohybrid material (SA-HEXAD) as well as it being a promising adsorbent in the adsorptive removal of anionic organic pollutants from aqueous solutions.

Shattar et al. also investigated how the natural montmorillonite can be utilized in the ametryn removal by adsorption [59]. They reported an upsurge in the ametryn adsorption upon raising the initial concentration as well as operating temperature, with basic medium derailing the adsorption process, producing maximum monolayer adsorption capacity of $188.81 \mathrm{mg} / \mathrm{g}$. Major contribution from the work include revealing the practicability of montmorillonite as a feasible answer in the search for secondary herbicide on-site treatment.

\subsection{Zeolites}

Zeolites are very important materials where conductive polymers are incorporated because of their large specific surface area, well-ordered porosity, and negatively charge-balanced exchangeable cations [102]. Zeolites like many other materials have their limitations which include abysmal adsorption performance of anions and organics. To address such limitations, modification methods are crucial with the popular among them being acid/base treatment and surfactant impregnation which alter the hydrophilic/hydrophobic nature in order for the adsorption capacity to be improved. Another limitation associated to zeolites is poor desorption with respect to various contaminants but that was compensated by the relatively low price. Various researchers reported the potentials of zeolites and various zeolite materials as adsorbents for the removal of pesticides with special focus dedicated to the coupling of zeolites with polyaniline (PANI) composites. Properties such as simple synthesis, low production cost, and high conductivity among others qualify PANI to be among the most crucial and well-studied conducting polymers [102]. The nature of PANI composite systems help in aiding the successful elimination of a wide range of toxic and ecotoxic substances [103-105].

Bajuk-Bogdanović and co. synthesized tungstophosphoric acid and BEA (HPW/BEA) zeolite composites by employing wetness impregnation method which was followed by ultrasonication and calcination [106]. Upon evaluating how efficient the prepared composites can be 
on the adsorptive removal of nicosulfuronpestcide in comparison to the parent zeolite, they revealed all the composites to be very good adsorbents with adsorption capacity of $12.1-25.8 \mathrm{mg}$ of nicosulfuron per gram. Something very important from their findings is that the entire prepared composite performed far better than the parent BEA zeolite in the nicosulfuron adsorption, and the results compared very well with activated carbon which was reported from literature as the most effective adsorbent for various processes.

\subsection{Metal organic frameworks (MOFs)}

Another class of crystalline organic-inorganic hybrid solids with the potentials of being an excellent adsorbent for wastewater treatment are metal organic frameworks (MOFs), applied in the removal of several hazardous pollutants from wastewater due to their large surface area and high porosity. Even though MOF-type materials are rated very high as promising adsorbent materials, there have been few reports on the use of MOFs as pesticide adsorbents. A simple solvothermal synthetic method was proposed by Yang et al. which lead to the fabrication of metal organic framework/-graphene oxide hybrid nanocomposite (UiO-67/GO), applied as an adsorbent for the removal of glyphosate pesticide from a polluted water [107]. They reported the adsorption process to take place in acidic medium at optimum $\mathrm{pH}$ of 4 , leading to the glyphosate adsorption capacity value of $482.69 \mathrm{mg} / \mathrm{g}$ with pseudo-second-order and Langmuir models as the best fit for the kinetic and equilibrium data respectively. Another important finding from the work is the dominant mechanisms of the adsorption process which was revealed to be in the form of surface/inner-complexation with functional groups of UiO-67/GO. Additionally, the work further suggested UiO-67/GO composite to show great potential as the next-generation adsorbent for wastewater treatment as well as opening the door for other MOF/GO composite materials to be fabricated for effective organic pollutant removal. In another development, a new magnetic MOF (M-MOF) was also synthesized by Liu et al. thereby by employing $\mathrm{Fe}_{4} \mathrm{O}_{3}-$ graphene oxide- $\beta$-cyclodextrin $\left(\mathrm{Fe}_{4} \mathrm{O}_{3}-\mathrm{GO}-\beta-\mathrm{CD}\right)$ nanocomposite as the magnetic core which was used for the rapid adsorption and removal of neonicotinoid insecticides in tap water samples [60]. The obtained MMOF has large surface area which resulted into adsorbent with high adsorption capacity for neonicotinoid insecticides. Upon applying the M-MOF adsorbent into spiked tap water samples for the neonicotinoid insecticide removal, the results suggested the developed MMOF to be simple and effective potential adsorbent.

Successful attempt was also made in the removal of 2 , 4-D molecules onto $\mathrm{CeO}_{2}$ nanofibers derived from CeBTC metal organic frameworks [108]. Hydrothermal method was applied in the adsorbent preparation. They calcinated the Ce-BTC nanoparticles at $650^{\circ} \mathrm{C}$ for $3 \mathrm{~h}$ with the obtained $\mathrm{CeO}_{2}$ nanofibers used for 2,4-D adsorption from water. Based on the adsorption results, the optimum adsorbent dose and contact time were 2.5 $\mathrm{mg}$ and $100 \mathrm{~min}$ respectively revealing three isotherm models (Langmuir, Freundlich, and Sips) to agree well with the experimental data. The 2,4-D maximum adsorption capacity values reported were $86.16,95.78$, and $84.29 \mathrm{mg} / \mathrm{g}$ at 298,308 , and $318 \mathrm{~K}$ respectively.

In another development, other researchers established an easy and dependable method of determining nine pesticide residues in tobacco using GC-MS coupled with magnetic solid phase extraction thereby synthesizing a novel magnetic Zr-MOF nanocomposite based on graphene with large surface area value of $178 \mathrm{~m}^{2} / \mathrm{g}$ as well as possessing high thermal stability and good magnetic response which was established to be well suited for the fast enrichment of multi-pesticides in tobacco matrix [61]. Various extraction conditions such as adsorbent dose, time of adsorption, eluting solvent, and desorption time were investigated with the whole pretreatment being accomplished within $10 \mathrm{~min}$. Acceptable recoveries in the range of 57.9 to $126.3 \%$ were obtained for the tobacco samples. Though the method shows low limit of detection, good reproducibility (relative standard deviations $<12.7 \%$ ) and wide linear range were very encouraging.

Some limitations associated with the MOFs include high cost coupled with complicated synthesis process; based on that, researchers are advised to seek for alternative routes which may lead to a relatively reduced cost and short synthesis time while producing MOFs in large scales.

\subsection{Equilibrium, kinetic modeling, and thermodynamic studies}

For every adsorption process, information derived from the isotherms, kinetic, and thermodynamic data are very crucial for the development of a design model that is accurate and effective in the removal of organic contaminants from aqueous media and/or synthetic wastewater. In order to effectively predict adsorbent performance in wastewater treatment, data generated from isotherm studies are very vital. Different isotherm models are reported to be useful but the most popular two-parameter isotherm models are the Langmuir and Freundlich models describing monolayer formation by chemisorptions as well as multilayer physical adsorption through weak van der Waals forces respectively [109]. The limitations of Langmuir and Freundlich models were highlighted to be their inability in fitting the generated equilibrium data over a wide range of concentration by their single set of constants, and hence proposed three- 
parameter isotherm equations (Redlich-Peterson, Sips, Toth models) to be more suitable since they encompassed additional parameters $(\mathrm{pH}$, temperature) and other interactions in the adsorption mechanism [110]. Two parameter isotherms were reported to be the most popular and widely used models in the majority of pesticide adsorption processes as compiled in Table 3, with most of the processes described by monolayer formation on the adsorbent surfaces as described by the Langmuir isotherm model.

Kinetic studies and modeling are also very crucial in describing and predicting the optimum adsorption conditions [111] as well as providing vital information about mechanisms of adsorption and also the presume ratecontrolling steps [112]. Pseudo-first- and pseudosecond-order kinetic models are the most popular and commonly applied in the pesticide adsorption studies. Despite their popularity, the models are handicapped such that they cannot recognize adsorption mechanisms. To address that drawback, other models such as Elovich and Weber-Morris were established and recommended [110]. In almost all the studied pesticide adsorption processes, only pseudo-first and pseudo-second-order models were employed by the researchers in explaining their generated kinetic data with lack of mechanism explanation using other aforementioned models well pronounced. As collated in Table 3, the best kinetic model that better interpreted pesticide adsorption processes was pseudo-second-order models.

Important thermodynamic parameters such as Gibbs free energy $\left(\Delta \mathrm{G}^{\mathrm{o}}\right)$, enthalpy change $\left(\Delta \mathrm{H}^{\circ}\right)$, and entropy change $\left(\Delta S^{\circ}\right)$ are also very useful in describing adsorption processes, thereby providing crucial information about the process spontaneity, endo- or exothermicity of an adsorption phenomenon, and randomness of the process. The adsorption mechanism can also be predicted from the thermodynamic parameters, for example, the predominant adsorption process mechanism can be said to be physisorption if $\Delta \mathrm{G}^{\circ}$ ranges from -20 and $0 \mathrm{~kJ} / \mathrm{mol}$, or chemisorptions if the values are in the range of -80 to $-400 \mathrm{~kJ} / \mathrm{mol}$.

\subsection{Economic consideration}

It is very uncommon to find adsorbent cost estimation in literature despite being the most important aspect to be considered in real-life application of adsorption processes. The estimated average price of zeolites and Fuller's earth were reported to be US\$ $0.03-0.12$ and US\$ $0.04 / \mathrm{kg}$ respectively $[113,114]$. While the market value of activated carbon was reported in literature by [115] to be in the range of US $\$ 2.0-2.2 / \mathrm{kg}$. The advantages of the low-cost adsorbents are their prices, because their usage, treatment, and the processes of regeneration are not economically friendly. In our own view, local availability, transportation, treatment process, recycling, and the lifetime of the adsorbents are fundamental factors to be considered when choosing an adsorbent [116, 117].

Treatment of an exhausted adsorbent is important but cumbersome, which has not been considered seriously. The sorption selectivity and capacity of adsorbents can be improved through some treatments as suggested in the literature [118]. Heat energy and large quantity of solvent are being consumed during the regeneration process of an adsorbent. All these modifications will acquire additional cost as well as that of transportation but there are few articles in literature that discuss on the subsequent cost of mentioned treatments. A high price adsorbent with the capabilities of multiple usages, cheap and simple regeneration process is considered an economical and promising material for adsorption processes. Therefore, the actual application involves appraising the adsorbent cost from its entire life cycle [119]. Some materials such as chitosan, cyclodextrin coupled with their composites show some distinguished outputs despite their limited practical applications which was linked to high cost and complex synthesis; for that, critical assessment of those materials is highly recommended especially those covering the whole life cycle.

\section{Conclusions}

A productive wastewater treatment is very important; therefore, it is necessary to find simple, cheap, and efficient advanced wastewater treatment techniques. These lead to good practices of water management and waste elimination, availability of clean water, increase in environmental nexus, and growth of the economy. There were different methods mentioned in literature, but adsorption has become more prominent in eliminating pesticide from wastewater as it is easy to handle and toxic free. Agricultural wastes, bio-sorbents, nano materials, inorganic wastes, and activated carbon were among many other adsorbents that were successfully applied with aim of eliminating pesticides from wastewater. The abovementioned adsorbents show good adsorptive properties in different examined tools. However, there are some important points that should be considered to have a good understanding of these adsorbent's adsorptive characteristics. Some studies focus on the determination of maximum adsorption capacities of synthetic pesticide solution in batch mode. Although the efficiency of an adsorbent does not depend only on their properties, it also relies on the adsorbent matrix characteristics as well as chemical revamping which can enhance the adsorption capacities due to having good adsorptive characteristics more than that of unmodified. This also leads to additional treatment cost of the chemical modification as well as creating secondary pollution from 
Table 3 List of experimental conditions, isotherm, kinetic models, and maximum adsorption capacities for the removal of pesticides on different adsorbent materials

\begin{tabular}{|c|c|c|c|c|c|c|}
\hline Adsorbents & Pesticides & $\begin{array}{l}\text { Experimental } \\
\text { conditions }\end{array}$ & $\begin{array}{l}\text { Isotherm } \\
\text { model }\end{array}$ & $\begin{array}{l}\text { Kinetic } \\
\text { model }\end{array}$ & $\begin{array}{l}\text { Maximum adsorption capacity } \\
(\mathrm{mg} / \mathrm{g})\end{array}$ & References \\
\hline Activated carbon-cloth & Dinoseb, ametryn, diuron, aldicarb & $\begin{array}{l}T=25^{\circ} \mathrm{C} \\
t=125 \mathrm{~min} \\
\mathrm{C}_{\mathrm{o}}=6.5 \times \\
10^{-5} \mathrm{~mol} / \mathrm{L}\end{array}$ & $\mathrm{F}$ & $\begin{array}{l}\text { Ps1 or } \\
\text { Ps2 }\end{array}$ & $\begin{array}{l}301.84 \text { (Dinoseb); } \\
354.61 \text { (ametryn); } \\
213.06 \text { (diuron); } \\
421.58 \text { (aldicarb) }\end{array}$ & [89] \\
\hline $\begin{array}{l}\text { Borassus aethiopum } \\
\text { shells-based activated } \\
\text { carbon }\end{array}$ & Carbofuran & $\begin{array}{l}\text { Adsorbent } \\
\text { dose }=0.15 \mathrm{~g} \\
\mathrm{pH}=2-12 \\
T=30{ }^{\circ} \mathrm{C} \\
t=18 \mathrm{~h} \\
C_{\circ}=30-200 \\
\mathrm{mg} / \mathrm{L}\end{array}$ & L & Ps2 & 160 & [17] \\
\hline $\begin{array}{l}\text { Granular activated } \\
\text { carbon (GAC F300) }\end{array}$ & Carbofuran and 2,4-D & $\begin{array}{l}\text { Adsorbent } \\
\text { dose }=0.20 \mathrm{~g} \\
\mathrm{pH}=6.35 \text { and } \\
3.5 \\
T=30{ }^{\circ} \mathrm{C} \\
t=26 \mathrm{~h} \\
\text { (carbofuran) } \\
\text { and } 8 \mathrm{~h}(2,4-\mathrm{D}) \\
\mathrm{C}_{\circ}=50-225 \\
\mathrm{mg} / \mathrm{L} \\
\text { (carbofuran) } \\
\text { and } 50-300 \\
\mathrm{mg} / \mathrm{L}(2,4-\mathrm{D})\end{array}$ & L & Ps2 & 96.15 (Carbofuran); 181.82 (2,4-D) & [38] \\
\hline $\begin{array}{l}\text { Date seed activated } \\
\text { carbon }\end{array}$ & Bentazon and carbofuran & $\begin{array}{l}\text { Adsorbent } \\
\text { dose }=0.20 \mathrm{~g} \\
\mathrm{pH}=2-12 \\
T=30{ }^{\circ} \mathrm{C} \\
t=0-36 \mathrm{~h} \\
\mathrm{C}_{\circ}=25-250 \\
\mathrm{mg} / \mathrm{L}\end{array}$ & $\mathrm{F}$ & Ps2 & $\begin{array}{l}86.26 \text { (bentazon); } 137.04 \\
\text { (carbofuran) }\end{array}$ & [40] \\
\hline $\begin{array}{l}\text { Mesoporous activated } \\
\text { carbon from starch } \\
\text { (ACS) }\end{array}$ & $\begin{array}{l}\text { Atrazine, pymetrozine, acetamiprid, } \\
\text { diuron, thiacloprid, imazalil, } \\
\text { difenoconazole, azoxystrobin, } \\
\text { pyraclostrobin, trifloxystrobin, and } \\
\text { chlorantraniliprole }\end{array}$ & $\begin{array}{l}\text { Adsorbent } \\
\text { dose }=5 \text { to } \\
120 \mathrm{mg}) \\
\mathrm{pH}=1-11 \\
T=25^{\circ} \mathrm{C} \\
t=0-4 \mathrm{~h} \\
\mathrm{C}_{\mathrm{o}}=0.5-2 \\
\mathrm{mg} / \mathrm{L}\end{array}$ & L & Ps2 & 66.2 (pyraclostrobin) & [42] \\
\hline $\begin{array}{l}\text { Waste rubber tire } \\
\text { activated carbon }\end{array}$ & $\begin{array}{l}\text { methoxychlor, atrazine and methyl } \\
\text { parathion }\end{array}$ & $\begin{array}{l}\text { Adsorbent } \\
\text { dose }=0.02- \\
0.14 \mathrm{~g} / \mathrm{L} \\
\mathrm{pH}=2-12 \\
T=25-45^{\circ} \mathrm{C} \\
t=0-150 \mathrm{~min} \\
\mathrm{C}_{\mathrm{o}}=2-12 \mathrm{mg} / \\
\mathrm{L}\end{array}$ & $\mathrm{L}$ & Ps1 & $\begin{array}{l}112.0 \text { (methoxychlor); } 104.9 \\
\text { (atrazine); } 88.9 \text { (methyl parathio) }\end{array}$ & [43] \\
\hline $\begin{array}{l}\text { Mesoporous activated } \\
\text { carbon from coconut } \\
\text { frond }\end{array}$ & Carbofuran & $\begin{array}{l}\text { Adsorbent } \\
\text { dose }=0.20 \mathrm{~g} \\
\mathrm{pH}=2-12 \\
T=30-50{ }^{\circ} \mathrm{C} \\
t=0-16 \mathrm{~h} \\
\mathrm{C}_{\circ}=25-250 \\
\mathrm{mg} / \mathrm{l}\end{array}$ & $\mathrm{F}$ & Ps2 & $\begin{array}{l}198.4\left(30^{\circ} \mathrm{C}\right) ; 193.1\left(40^{\circ} \mathrm{C}\right) ; 205.0 \\
\left(50^{\circ} \mathrm{C}\right)\end{array}$ & [48] \\
\hline $\begin{array}{l}\text { Activated carbon from } \\
\text { waste hemp }\end{array}$ & $\begin{array}{l}\text { Acetamiprid, dimethoate, } \\
\text { nicosulfuron, carbofuran, and } \\
\text { atrazine }\end{array}$ & $\begin{array}{l}\text { Adsorbent } \\
\text { dose }=0.20 \mathrm{~g} \\
T=25^{\circ} \mathrm{C} \\
t=0-200 \mathrm{~min} \\
\mathrm{C}_{\mathrm{O}}=10-50 \\
\mathrm{mg} / \mathrm{L}\end{array}$ & $\mathrm{F}$ & - & $\begin{array}{l}12.20 \text { (acetamiprid,); } 11.80 \\
\text { (dimethoate); } 19.50 \text { (nicosulfuron); } \\
15.40 \text { (carbofuran); } 15.50 \text { (atrazine) }\end{array}$ & [49] \\
\hline $\begin{array}{l}\text { Coconut shell activated } \\
\text { carbon }\end{array}$ & Malathion & $\begin{array}{l}\text { Adsorbent } \\
\text { dose }=1.0 \mathrm{~g}\end{array}$ & L & - & 909.1 & [50] \\
\hline
\end{tabular}


Table 3 List of experimental conditions, isotherm, kinetic models, and maximum adsorption capacities for the removal of pesticides on different adsorbent materials (Continued)

\begin{tabular}{|c|c|c|c|c|c|c|}
\hline Adsorbents & Pesticides & $\begin{array}{l}\text { Experimental } \\
\text { conditions }\end{array}$ & $\begin{array}{l}\text { Isotherm } \\
\text { model }\end{array}$ & $\begin{array}{l}\text { Kinetic } \\
\text { model }\end{array}$ & $\begin{array}{l}\text { Maximum adsorption capacity } \\
(\mathrm{mg} / \mathrm{g})\end{array}$ & References \\
\hline & & $\begin{array}{l}T=30-80{ }^{\circ} \mathrm{C} \\
t=30-300 \\
\min \\
C_{0}=7 \mu \mathrm{g} / \mathrm{L}\end{array}$ & & & & \\
\hline $\begin{array}{l}\mathrm{NH}_{4} \mathrm{Cl} \text {-induced } \\
\text { activated carbon }\end{array}$ & Diazinon & $\begin{array}{l}\mathrm{pH}=2-10 \\
T=25-40{ }^{\circ} \mathrm{C} \\
t=0-6 \mathrm{~h} \\
\mathrm{C}_{\mathrm{o}}=2-10 \mathrm{mg} / \\
\mathrm{L} \\
\text { NAC } \\
\text { concentration } \\
(0.1-0.3 \mathrm{~g} / \mathrm{L})\end{array}$ & $\mathrm{L}$ & Ps2 & 250.00 & [51] \\
\hline $\begin{array}{l}\text { Treated watermelon } \\
\text { peels }\end{array}$ & Methyl parathion & $\begin{array}{l}\text { Adsorbent } \\
\text { dose }=0.05-1 \\
\mathrm{~g} \\
\mathrm{pH}=1-10 \\
T=10-50{ }^{\circ} \mathrm{C} \\
t=10-100 \\
\mathrm{~min} \\
\mathrm{C}_{\mathrm{O}}=0.38-3.8 \\
\times 10^{-4} \mathrm{~mol} / \mathrm{L}\end{array}$ & $D-R$ & Ps1 & $24.3 \pm 1.6 \mu \mathrm{mol} / \mathrm{g}$ & [90] \\
\hline Chestnut shells & $\begin{array}{l}\text { Imidacloprid, acetamiprid, and } \\
\text { thiamethoxam }\end{array}$ & $\begin{array}{l}\text { Adsorbent } \\
\text { dose }=7.2 \mathrm{~g} \\
\mathrm{pH}=\text { acidic } \\
T=25^{\circ} \mathrm{C} \\
t=48 \mathrm{~h} \\
\mathrm{C}_{0}=5 \mathrm{mg} / \mathrm{L}\end{array}$ & $\mathrm{F}$ & Ps2 & $\begin{array}{l}8.5070 \text { (imidacloprid); } 4.6984 \\
\text { (acetamiprid); } 14.310 \\
\text { (thiamethoxam) }\end{array}$ & [91] \\
\hline $\begin{array}{l}\text { Fungus Pleurotus } \\
\text { mutilus }\end{array}$ & Metribuzin & $\begin{array}{l}\text { Adsorbent } \\
\text { dose }=1-4 \mathrm{~g} \\
\mathrm{pH}=2-8 \\
T=25^{\circ} \mathrm{C} \\
t=0-25 \mathrm{~min} \\
\mathrm{C}_{\mathrm{o}}=100-400 \\
\mathrm{mg} / \mathrm{L} \\
\text { Particle size = } \\
\text { 0-625 } \mathrm{mm}\end{array}$ & - & - & 3.3 & [96] \\
\hline $\begin{array}{l}\text { Graphitic carbon } \\
\text { nanostructures from } \\
\text { filter paper }\end{array}$ & $2,4-\mathrm{D}$ & $\begin{array}{l}\text { Adsorbent } \\
\text { dose }=2 \mathrm{mg} \\
\mathrm{pH}=2-10 \\
T=30{ }^{\circ} \mathrm{C} \\
t=0-24 \mathrm{~h} \\
\mathrm{C}_{\circ}=9-300 \\
\mathrm{mg} / \mathrm{L}\end{array}$ & R-P & $\begin{array}{l}\text { E and } \\
\text { M-e }\end{array}$ & 77.13 & {$[52]$} \\
\hline $\begin{array}{l}\text { Graphitic carbon } \\
\text { nanostructures from } \\
\text { cotton }\end{array}$ & $2,4-D$ & $\begin{array}{l}\text { Adsorbent } \\
\text { dose }=2 \mathrm{mg} \\
\mathrm{pH}=2-10 \\
T=30{ }^{\circ} \mathrm{C} \\
t=0-24 \mathrm{~h} \\
\mathrm{C}_{\circ}=9-300 \\
\mathrm{mg} / \mathrm{L}\end{array}$ & R-P & $\begin{array}{l}\text { E and } \\
\text { M-e }\end{array}$ & 26.93 & {$[52]$} \\
\hline $\begin{array}{l}\text { Phenyl-modified } \\
\text { magnetic graphene/ } \\
\text { mesoporous silica }\end{array}$ & $\begin{array}{l}\text { Avermectin, imidacloprid, } \\
\text { pyridaben, dichlorvos, acetamiprid, } \\
\text { dursban, isocarbophos, and } \\
\text { phoxim }\end{array}$ & $\begin{array}{l}\text { Adsorbent } \\
\text { dose }=100 \\
\mathrm{mg} \\
\mathrm{pH}=2-12 \\
T=25-35^{\circ} \mathrm{C} \\
t=0-2 \mathrm{~h} \\
C_{\mathrm{O}}=391- \\
48430 \mu \mathrm{g} / \mathrm{L}\end{array}$ & $\mathrm{F}$ & Ps1 & $\begin{array}{l}9.208 \text { (Avermectin); } 6.404 \\
\text { (Imidacloprid); } 12.72 \text { (Pyridaben); } \\
47.78 \text { (Dichlorvos); } 5.108 \\
\text { (Acetamiprid); } 8.010 \text { (Dursban); } \\
\text { 2.877 (Isocarbophos); } 8.233 \\
\text { (Phoxim) }\end{array}$ & [53] \\
\hline $\begin{array}{l}\text { Mesoporous carbon } \\
\text { derived from a } \\
\text { biopolymer and a clay }\end{array}$ & Dicamba Pestanal & $\begin{array}{l}\text { Adsorbent } \\
\text { dose }=30 \mathrm{mg} \\
\mathrm{pH}=2-11 \\
T=25-55^{\circ} \mathrm{C}\end{array}$ & L & Ps2 & 251.9 & [54] \\
\hline
\end{tabular}


Table 3 List of experimental conditions, isotherm, kinetic models, and maximum adsorption capacities for the removal of pesticides on different adsorbent materials (Continued)

\begin{tabular}{|c|c|c|c|c|c|c|}
\hline Adsorbents & Pesticides & $\begin{array}{l}\text { Experimental } \\
\text { conditions }\end{array}$ & $\begin{array}{l}\text { Isotherm } \\
\text { model }\end{array}$ & $\begin{array}{l}\text { Kinetic } \\
\text { model }\end{array}$ & $\begin{array}{l}\text { Maximum adsorption capacity } \\
(\mathrm{mg} / \mathrm{g})\end{array}$ & References \\
\hline & & $\begin{array}{l}t=0.3-2 \mathrm{~h} \\
C_{0}=25-1000 \\
\mathrm{mg} / \mathrm{L}\end{array}$ & & & & \\
\hline $\begin{array}{l}\text { Graphene oxide-based } \\
\text { silica-coated magnetic } \\
\text { nanoparticles function- } \\
\text { alized with 2- } \\
\text { phenylethylamine }\end{array}$ & $\begin{array}{l}\text { Chlorpyrifos, parathion, and } \\
\text { malathion }\end{array}$ & $\begin{array}{l}\text { Adsorbent } \\
\text { dose }=2-40 \\
\mathrm{mg} \\
\mathrm{pH}=3-11 \\
T=25^{\circ} \mathrm{C} \\
t=0-1 \mathrm{~h} \\
\mathrm{C}_{\mathrm{o}}=0.3-5 \mu \mathrm{g} / \\
\mathrm{mL}\end{array}$ & sips & Ps2 & $\begin{array}{l}25.6 \text { (chlorpyrifos); } 135 \text { (parathion); } \\
61.9 \text { (malathion) }\end{array}$ & {$[55]$} \\
\hline Four Indian soils & $\begin{array}{l}\text { a-endosulfan } \\
\beta \text {-endosulfan }\end{array}$ & $\begin{array}{l}\text { Adsorbent } \\
\text { dose }=5 \mathrm{~g} \\
\mathrm{pH}=2-8 \\
T=28^{\circ} \mathrm{C} \\
t=0.25-24 \mathrm{~h} \\
\mathrm{C}_{\mathrm{o}}=0.15-100 \\
\mathrm{mg} / \mathrm{L}\end{array}$ & L & - & $\begin{array}{l}0.10-0.45 \text { (a-endosulfan) } \\
0.094-0.272 \text { ( } \beta \text {-endosulfan) }\end{array}$ & [99] \\
\hline $\begin{array}{l}\text { Natural } \\
\text { montmorillonite }\end{array}$ & Ametryn & $\begin{array}{l}\text { Adsorbent } \\
\text { dose }=0.20 \mathrm{~g} \\
\mathrm{pH}=2-12 \\
T=30-50{ }^{\circ} \mathrm{C} \\
t=0-7 \mathrm{~h} \\
C_{O}=25-150 \\
\mathrm{mg} / \mathrm{L}\end{array}$ & L & Ps2 & 188.81 & [59] \\
\hline $\begin{array}{l}\text { Polyaniline/BEA zeolite } \\
\text { composites }\end{array}$ & Nicosulfuron & $\begin{array}{l}\text { Adsorbent } \\
\text { dose }=20 \mathrm{mg} \\
\mathrm{pH}=5 \\
T=23{ }^{\circ} \mathrm{C} \\
t=0-40 \mathrm{~h} \\
\mathrm{C}_{\circ}=10-100 \\
\mathrm{mg} / \mathrm{L}\end{array}$ & $L-F$ & - & $\begin{array}{l}\text { 18.4-25.4 (Protonated PANI/BEA } \\
\text { composites); } 18.2 \text { (pristine BEA } \\
\text { zeolite); } 29.8 \text { (PANIs) }\end{array}$ & [102] \\
\hline $\begin{array}{l}\text { Magnetic graphene } \\
\text { oxide-cyclodextrin }\end{array}$ & $\begin{array}{l}\text { Thiamethoxam, imidacloprid, } \\
\text { acetamiprid, nitenpyram, } \\
\text { dinotefuran, clothianidin, and } \\
\text { thiacloprid }\end{array}$ & $\begin{array}{l}\text { Adsorbent } \\
\text { dose }=5 \mathrm{mg} \\
\mathrm{pH}=2-11 \\
t=0-120 \mathrm{~min} \\
\mathrm{C}_{\mathrm{o}}=0.5-100 \\
\mathrm{mg} / \mathrm{L}\end{array}$ & $\mathrm{F}$ & Ps2 & $\begin{array}{l}0.558 \text { (thiamethoxam); } 0.363 \\
\text { (imidacloprid); } 0.362 \text { (acetamiprid); } \\
0.639 \text { (nitenpyram); } 0.533 \\
\text { (dinotefuran); } 0.412 \text { (clothianidin), } \\
\text { and } 0.275 \text { (thiacloprid) }\end{array}$ & {$[60]$} \\
\hline $\mathrm{LaFe}_{0.9} \mathrm{CO}_{0.1} \mathrm{O}_{3}$ & Vitavax & $\begin{array}{l}\text { Adsorbent } \\
\text { dose }=1-3 \mathrm{~g} / \\
\mathrm{L} \\
T=15-45^{\circ} \mathrm{C} \\
t=5-40 \mathrm{~min} \\
C_{0}=200-800 \\
\mathrm{mg} / \mathrm{L}\end{array}$ & L & Ps1 & 166.67 & [64] \\
\hline $\mathrm{LaFe}_{0.1} \mathrm{Co}_{0.9} \mathrm{O}_{3}$ & Vitavax & $\begin{array}{l}\text { Adsorbent } \\
\text { dose }=1-3 \mathrm{~g} / \\
\mathrm{L} \\
T=15-45^{\circ} \mathrm{C} \\
t=5-40 \mathrm{~min} \\
C_{\circ}=200-800 \\
\mathrm{mg} / \mathrm{L}\end{array}$ & L & Ps1 & 142.86 & [64] \\
\hline $\begin{array}{l}\text { Multi-walled carbon } \\
\text { nanotubes }\end{array}$ & Diazinon & $\begin{array}{l}\text { Adsorbent } \\
\text { dose }=0.1 \\
\text { and } 0.3 \mathrm{~g} / \mathrm{L} \\
\mathrm{pH}=4 \text { and } 7 \\
T=24^{\circ} \mathrm{C} \\
t=1-15 \mathrm{~min} \\
C_{0}=0-100 \\
\mathrm{mg} / \mathrm{L}\end{array}$ & - & - & - & {$[62]$} \\
\hline Modified chitosan & Pentachlorophenol & Adsorbent & R-P & Ps2 & $36.85\left(20^{\circ} \mathrm{C}\right) ; 32.19\left(30^{\circ} \mathrm{C}\right) ; 22.35$ & [63] \\
\hline
\end{tabular}


Table 3 List of experimental conditions, isotherm, kinetic models, and maximum adsorption capacities for the removal of pesticides on different adsorbent materials (Continued)

\begin{tabular}{|c|c|c|c|c|c|c|}
\hline Adsorbents & Pesticides & $\begin{array}{l}\text { Experimental } \\
\text { conditions }\end{array}$ & $\begin{array}{l}\text { Isotherm } \\
\text { model }\end{array}$ & $\begin{array}{l}\text { Kinetic } \\
\text { model }\end{array}$ & $\begin{array}{l}\text { Maximum adsorption capacity } \\
(\mathrm{mg} / \mathrm{g})\end{array}$ & References \\
\hline material & & $\begin{array}{l}\text { dose }=0.02- \\
0.20 \mathrm{~g} \\
\mathrm{pH}=2-12 \\
T=20-40{ }^{\circ} \mathrm{C} \\
t=0-3 \mathrm{~h} \\
C_{\circ}=0-100 \\
\mathrm{mg} / \mathrm{L}\end{array}$ & & & $\left(40^{\circ} \mathrm{C}\right)$ & \\
\hline $\begin{array}{l}\text { Algerian palygorskite } \\
\text { modified with } \\
\text { magnetic iron (Pur Pal); } \\
\left.\left.(\mathrm{FeO} \mathrm{Pal})_{1}\right) \text { ( } \mathrm{FeO} \mathrm{Pal}_{2}\right) \text {; }\end{array}$ & Linuron & $\begin{array}{l}\text { Adsorbent } \\
\text { dose }=0.025 \mathrm{~g} \\
\text { to } 0.2 \mathrm{~g} \\
T=20^{\circ} \mathrm{C} \\
t=0-1400 \\
\mathrm{~min} \\
\mathrm{C}_{\mathrm{o}}=0.5-10 \\
\mathrm{mg} / \mathrm{L}\end{array}$ & $\mathrm{F}$ & Ps2 & $\begin{array}{l}\text { Pur Pal-545; } \\
\text { FeO Pal } 1 \text {-1099; } \\
\text { FeO Pal } 2-1695\end{array}$ & [67] \\
\hline $\begin{array}{l}\text { Copper modified } \\
\text { microcrystalline } \\
\text { cellulose }\end{array}$ & Prometryn & $\begin{array}{l}\text { Adsorbent } \\
\text { dose }=0.1- \\
1.5 \mathrm{~g} \\
\mathrm{pH}=2-14 \\
T=30-50^{\circ} \mathrm{C} \\
t=0-24 \mathrm{~h} \\
C_{\circ}=30-150 \\
\mathrm{mg} / \mathrm{L} \\
\text { Shaking speed } \\
=100-250 \\
\mathrm{rpm}\end{array}$ & $\mathrm{L}$ & Ps2 & 97.80 & {$[68]$} \\
\hline
\end{tabular}

2,4,5-T 2,4,5-trichlorophenoxy acetic acid, 2,4-D 2,4-dichlorophenoxyacetic, 4-CPA 4-chlorophenoxyacetic acid, CFA 2-(4-chlorophenoxy)-2-methylpropionic acid, Ps1 pseudo-first-order model, Ps2 pseudo-second-order model, $E$ Elovich, $L$ Langmuir, $F$ Freundlich, $R$ - $P$ Redlich-Peterson, $M$-e M-exponential, $P A N I s$ polyanilines, $P E I$ polyethyleneimine, $J$ Jossens, Pur Pal colloidal solution of $\mathrm{Fe}_{3} \mathrm{O}_{4}$ with a $1 \%$ mass dispersion of purified palygorskite, FeO Pal ${ }_{1}$ non-hydrothermally treated magnetic $\mathrm{FeO} \mathrm{Pal}$ nanoparticles, $\mathrm{FeO} \mathrm{Pal}_{2}$ hydrothermally treated magnetic $\mathrm{FeO}$ Pal nanoparticles

leaching of chemicals during modification treatments. There is need for extensive review on the secondary pollution caused during the modification of adsorbents which is rarely reported by the articles gathered in this review. Two parameter isotherms such as Freundlich and Langmuir are recommended to be examined alongside with three parameter models such as Sips and Toth in equilibrium modeling as this will give a comprehensive understanding of adsorption pathway. In the kinetic studies, Elovich and Weber and Morris kinetic models need to be studied to comprehend and investigate the in-depth adsorption pathways. This is vital because adsorption mechanism cannot be identified correctly by only the pseudo-first-order and pseudo-second-order models. The thermodynamic parameters that are temperature dependent should be examined with caution due the observation of an enthalpy-entropy compensation.

The disposal of pesticide-loaded wastes from adsorption processes demands urgent attention. The ability of an adsorbent to be reused is an important element in cost effectiveness. The reuse and regeneration of adsorbents are discussed in some studies while some do not, so detailed assessment of the regeneration of adsorbents are highly recommended for the adsorption process to be economically achievable. Cost analysis on the adsorbents practical application is also very crucial and should be incorporated in further researches that involve pesticide removal from wastewater using adsorption method.

\section{Abbreviations}

OCPs: Organochlorine pesticides; SPs: Synthetic pyrethroids;

OPPs: Organophosphorus pesticides; PMOCs: Persistent and mobile organic compounds; HCH: Hexachlorocyclohexane; BP: Bromopropylate; DSAC: Date seed activated carbon; ACS: Activated carbon from starch; GCB: Graphitized carbon black; MP: Methyl parathion; CoDa: Compositional data analysis; GCNP: Magnetic nanoparticles prepared from filter paper; GCN-C: Magnetic nanoparticles prepared from cotton; PEA: 2-Phenylethylamine;

OHTs: Organohydrotalcites; HT-DDS: Intercalated with dodecylsulfate; HTTDD: Intercalated with tetradecanedioate; PANI: Polyaniline coupled with zeolites; MOFs: Metal organic frameworks; 2,4,5-T: 2,4,5-Trichlorophenoxy acetic acid; 2,4-D: 2,4-Dichlorophenoxyacetic; 4-CPA: Chlorophenoxyacetic acid; CFA: 2-(4-Chlorophenoxy)-2-methylpropionic acid; Ps1: Pseudo-firstorder model; Ps2: Pseudo-second-order model; E: Elovich; L: Langmuir; F: Freundlich; R-P: Redlich-Peterson; M-e: M-exponential; PANIs: Polyanilines; PEl: Polyethyleneimine; J: Jossens; Pur Pal: Colloidal solution of $\mathrm{Fe}_{3} \mathrm{O}_{4}$ with a $1 \%$ mass dispersion of purified palygorskitel; FeO Pal ${ }_{1}$ : Non-hydrothermally treated magnetic FeO Pal nanoparticles; FeO Pal 2 : Hydrothermally treated magnetic FeO Pal nanoparticles

\section{Acknowledgements}

I would like to show gratitude to colleagues in the Department of Chemistry, ABU Zaria, Nigeria, who provided insights, expertise, and support that greatly assisted in writing the article. 


\section{Authors' contributions}

ZNG selected the topic and wrote manuscript. AKA, AH, and SAG contributed some part of the manuscript and proof read. All authors read and approved the final manuscript.

\section{Funding}

No funding was received for this research work.

\section{Availability of data and materials}

No additional data and material other than the manuscript is to be produced.

\section{Declarations}

Ethics approval and consent to participate

Not applicable.

\section{Consent for publication}

Not applicable.

\section{Competing interests}

The authors declare that they have no competing interests.

\section{Author details}

${ }^{1}$ Department of Chemistry, Ahmadu Bello University, Zaria, Nigeria. ${ }^{2}$ Centre for Technical and Vocational Training, Air Force Institute of Technology, Kaduna, Nigeria.

\section{Received: 16 December 2020 Accepted: 2 March 2021}

Published online: 22 March 2021

\section{References}

1. Lu Y, Song S, Wang R, Liu Z, Meng J, Sweetman AJ, Jenkins A, Ferrier RC, Li H, Luo W, Wang T (2015) Impacts of soil and water pollution on food safety and health risks in China. Enviro Intl 77:5-15. https://doi.org/10.1016/j. envint.2014.12.010

2. Galadima A, Garba ZN, Leke L, Almustapha MN, Adam IK (2011) Domestic water pollution among local communities in Nigeria ----causes and consequences. Eur J Sci Res 52(4):592-603

3. Surip SN, Abdulhameed AS, Garba ZN, Syed-Hassan SSA, Ismail K, Jawad AH (2020) $\mathrm{H}_{2} \mathrm{SO}_{4}$-treated Malaysian low rank coal for methylene blue dye decolourization and cod reduction: optimization of adsorption and mechanism study. Surf Interf 21:100641. https://doi.org/10.1016/j.surfin.202 0.100641

4. Tan CHC, Sabar S, Haafiz MKM, Garba ZN, Hussin MH (2020) The improved adsorbent properties of microcrystalline cellulose from oil palm fronds through immobilization technique. Surf Interf 20:100614

5. Garba ZN, Lawan I, Zhou W, Zhang M, Wang L, Yuan Z (2020) Microcrystalline cellulose (MCC) based materials as emerging adsorbents for the removal of dyes and heavy metals - a review. Sci Total Environ 717: 135070. https://doi.org/10.1016/j.scitotenv.2019.135070

6. Garba ZN, Zhou W, Zhang M, Yuan Z (2020) A review on the preparation, characterization and potential application of perovskites as adsorbents for wastewater treatment. Chemosphere 244:125474. https://doi.org/10.1016/j. chemosphere.2019.125474

7. Garba ZN, Xiao W, Zhou W, Lawan I, Jiang Y, Zhang M, Yuan Z (2019) Process optimization and synthesis of lanthanum-cobalt perovskite type nanoparticles (LaCoO3) prepared by modified proteic method: application of response surface methodology. Korean J Chem Eng 36(11):1826-1838. https://doi.org/10.1007/s1 1814-019-0400-1

8. Okibe FG, Garba ZN, Alimi JM (2018) Optimization of the conditions for adsorption of fluoride in aqueous solution by carrot residue using central composite design of experiment. Bayero J Pure Appl Sci 11:230-237

9. Xiao W, Jiang X, Liu X, Zhou W, Garba ZN, Lawan I, Wang L, Yuan Z (2020) Adsorption of organic dyes from wastewater by metal-doped porous carbon materials. J Clean Prod 284:124773

10. Grung M, Lin Y, Zhang H, Steen AO, Huang J, Zhang G, Larssen T (2015) Pesticide levels and environmental risk in aquatic environments in China - a review. Environ Int 81:87-97. https://doi.org/10.1016/j.envint.2015.04.013

11. Singare PU (2015) Persistent organic pesticide residues in sediments of Vasai Creek near Mumbai: assessment of sources and potential ecological risk. Mar Pollut Bull 100(1):464-475. https://doi.org/10.1016/j.marpolbul.2015. 09.033

12. Li H, Cheng F, Wei Y, Lydy MJ, You J (2017) Global occurrence of pyrethroid insecticides in sediment and the associated toxicological effects on benthic invertebrates: an overview. J Hazard Mater 324(Pt B):258-271. https://doi. org/10.1016/j.jhazmat.2016.10.056

13. McKnight US, Rasmussen JJ, Kronvang B, Binning PJ, Bjerg PL (2015) Sources, occurrence and predicted aquatic impact of legacy and contemporary pesticides in streams. Environ Pollut 200:64-76. https://doi. org/10.1016/j.envpol.2015.02.015

14. Korkmaz V, Güngördü A, Ozmen M (2018) Comparative evaluation of toxicological effects and recovery patterns in zebrafish (Danio rerio) after exposure to phosalone-based and cypermethrin-based pesticides. Ecotoxicol Environ Saf 160:265-272. https://doi.org/10.1016/j.ecoenv.2018.05.055

15. Tsaboula A, Papadakis E-N, Vryzas Z, Kotopoulou A, Kintzikoglou K, Papadopoulou-Mourkidou E (2016) Environmental and human risk hierarchy of pesticides: a prioritization method, based on monitoring, hazard assessment and environmental fate. Environ Int 91:78-93. https://doi.org/1 0.1016/j.envint.2016.02.008

16. Zheng S, Chen B, Qiu X, Chen M, Ma Z, Yu X (2016) Distribution and risk assessment of 82 pesticides in Jiulong River and estuary in South China. Chemosphere 144:1177-1192. https://doi.org/10.1016/j.chemosphere.2015. 09.050

17. Garba ZN, Tanimu A, Zango ZU (2019) Borassus aethiopum shell-based activated carbon as efficient adsorbent for carbofuran. Bull Chem Soc Ethiop 33(3):425-436. https://doi.org/10.4314/bcse.v33i3.4

18. Masiá A, Campo J, Navarro-Ortega A, Barceló D, Picó Y (2015) Pesticide monitoring in the basin of Llobregat River (Catalonia, Spain) and comparison with historical data. Sci Total Environ 503:58-68

19. Net S, Rabodonirina S, Sghaier RB, Dumoulin D, Chbib C, Tlili I, Ouddane B (2015) Distribution of phthalates, pesticides and drug residues in the dissolved, particulate and sedimentary phases from transboundary rivers (France-Belgium). Sci Total Environ 521:152-159

20. Roknul Azam SM, Ma H, Xu B, Devi S, Siddique MAB, Stanley SL, Bhandari B, Zhu J (2020) Efficacy of ultrasound treatment in the and removal of pesticide residues from fresh vegetables: a review. Trends Food Sci Technol 97:417-432. https://doi.org/10.1016/j.tifs.2020.01.028

21. Pandiselvam $R$, Kaavya $R$, Jayanath $Y$, Veenuttranon $K$, Lueprasitsakul $P$, Divya V, Kothakota A, Ramesh SV (2019) Ozone as a novel emerging technology for the dissipation of pesticide residues in foods-a review. Trends Food Sci Technol 97:38-54

22. Meftaul IM, Venkateswarlu K, Dharmarajan R, Annamalai P, Megharaj M (2020) Pesticides in the urban environment: a potential threat that knocks at the door. Sci Total Environ 711:134612. https://doi.org/10.1016/j.scitotenv.2 019.134612

23. Wołejko E, Jabłońska-Trypuć A, Wydro U, Butarewicz A, Łozowicka B (2020) Soil biological activity as an indicator of soil pollution with pesticides - a review. Appl Soil Ecol 147:103356

24. de Souza RM, Seibert D, Quesada HB, Bassetti FJ, Fagundes-Klen MR, Bergamasco R (2020) Occurrence, impacts and general aspects of pesticides in surface water: a review. Proc Saf Environ Prot 135:22-37. https://doi.org/1 0.1016/j.psep.2019.12.035

25. Sabarwal A, Kumar K, Singh RP (2018) Hazardous effects of chemical pesticides on human health-cancer and other associated disorders. Environ Toxicol Pharmacol 63:103-114. https://doi.org/10.1016/j.etap.2018.08.018

26. Chawla P, Kaushik R, Swaraj VJS, Kumar N (2018) Organophosphorus pesticides residues in food and their colorimetric detection. Environ Nanotechnol Monit Manage 10:292-307. https://doi.org/10.1016/j.enmm.201 8.07.013

27. Morillo E, Villaverde J (2017) Advanced technologies for the remediation of pesticide-contaminated soils. Sci Total Environ 586:576-597. https://doi. org/10.1016/j.scitotenv.2017.02.020

28. Bapat G, Labade C, Chaudhari A, Zinjarde S (2016) Silica nanoparticle based techniques for extraction, detection, and degradation of pesticides. Adv Colloid Interf Sci 237:1-14. https://doi.org/10.1016/j.cis.2016.06.001

29. Reddy PVL, Kim K-H (2015) A review of photochemical approaches for the treatment of a wide range of pesticides. J Hazard Mater 285:325-335. https://doi.org/10.1016/j.jhazmat.2014.11.036

30. Sjerps RMA, Kooij PJF, van Loon A, Van Wezel AP (2019) Occurrence of pesticides in Dutch drinking water sources. Chemosphere 235:510-518. https://doi.org/10.1016/j.chemosphere.2019.06.207 
31. Bernhardt ES, Rosi EJ, Gessner MO (2017) Synthetic chemicals as agents of global change. Front Ecol Environ 15(2):84-90. https://doi.org/10.1002/fee.14 50

32. Gonzalez-Rodríguez RM, Rial-Otero R, Cancho-Grande B, Gonzalez-Barreiro C, Simal-Gandara J (2011) 51, a review on the fate of pesticides during the processes within the food-production Chain. Crit Rev Food Sci Nutr 51(2): 99-114. https://doi.org/10.1080/10408390903432625

33. Heuvelink GBM, Burgers SLGE, Tiktak A, Den Berg FV (2010) Uncertainty and stochastic sensitivity analysis of the GeoPEARL pesticide leaching model. Geoderma 155(3-4):186-192. https://doi.org/10.1016/j.geoderma.2009.07.004

34. van Eerdt MM, Spruijt J, van der Wal E, van Zeijts H, Tiktak A (2014) Costs and effectiveness of on-farm measures to reduce aquatic risks from pesticides in the Netherlands. Pest Manag Sci 70(12):1840-1849. https://doi. org/10.1002/ps.3729

35. Stuart M, Lapworth D, Crane E, Hart A (2012) Review of risk from potential emerging contaminants in UK groundwater. Sci Total Environ 416:1-21. https://doi.org/10.1016/j.scitotenv.2011.11.072

36. Reemtsma T, Alder L, Banasiak U (2013) Emerging pesticide metabolites in groundwater and surface water as determined by the application of a multimethod for 150 pesticide metabolites. Water Res 47:5535-5545

37. Sjerps RMA, ter Laak TL, Zwolsman GJJG (2017) Projected impact of climate change and chemical emissions on the water quality of the European rivers Rhine and Meuse: a drinking water perspective. Sci Total Environ 601-602: 1682-1694

38. Salman JM, Hameed BH (2010) Adsorption of 2,4-dichlorophenoxyacetic acid and carbofuran pesticides onto granular activated carbon. Desalination 256(1-3):129-135. https://doi.org/10.1016/j.desal.2010.02.002

39. Ignatowicz K (2011) A mass transfer model for the adsorption of pesticide on coconut shell based activated carbon. Int J Heat Mass Transf 54(23-24): 4931-4938. https://doi.org/10.1016/j.ijheatmasstransfer.2011.07.005

40. Salman JM, Njoku VO, Hameed BH (2011) Bentazon and carbofuran adsorption onto date seed activated carbon: kinetics and equilibrium. Chem Eng J 173(2):361-368. https://doi.org/10.1016/j.cej.2011.07.066

41. Salman JM (2014) Optimization of preparation conditions for activated carbon from palm oil fronds using response surface methodology on removal of pesticides from aqueous solution. Arab J Chem 7(1):101-108. https://doi.org/10.1016/j.arabjc.2013.05.033

42. Suo F, Liu X, Li C, Yuan M, Zhang B, Wang J, Ma Y, Lai Z, Ji M (2019) Mesoporous activated carbon from starch for superior rapid pesticides removal. Int J Biol Macromol 121:806-813. https://doi.org/10.1016/j.ijbioma c.2018.10.132

43. Gupta VK, Gupta B, Rastogi A, Agarwal S, Nayak A (2011) Pesticides removal from waste water by activated carbon prepared from waste rubber tire. Water Res 45:4047-4055

44. Derylo-Marczewska A, Blachnio M, Marczewski AW, Seczkowska M, Tarasiuk B (2019) Phenoxyacid pesticide adsorption on activated carbon equilibrium and kinetics. Chemosphere 214:349-360. https://doi.org/10.101 6/j.chemosphere.2018.09.088

45. Ioannidou QA, Zabaniotou AA, Stavropoulos GG, Islam MA, Albanis TA (2010) Preparation of activated carbons from agricultural residues for pesticide adsorption. Chemosphere 80(11):1328-1336. https://doi.org/10.101 6/j.chemosphere.2010.06.044

46. Prasertmanukitch S, Tierney MJ, Waszkiewicz SD, Saidani H, Riceh I (2004) Measurement of the adsorptive capacity of a powder. Sep Purif Technol 40(3):267-277. https://doi.org/10.1016/j.seppur.2004.03.004

47. Diamantopoulou I, Skodras G, Sakellaropoulos GP (2010) Sorption of mercury by activated carbon in the presence of flue gas components. Fuel Process Technol 91(2):158-163. https://doi.org/10.1016/j.fuproc.2009. 09.005

48. Njoku VO, Islam MA, Asif M, Hameed BH (2014) Preparation of mesoporous activated carbon from coconut frond for the adsorption of carbofuran insecticide. J Anal Appl Pyrolysis 110:172-180. https://doi.org/10.1016/j.jaa p.2014.08.020

49. Vukcevic MM, Kalijadis AM, Vasiljevic TM, Babic BM, Lausevic ZV, Lausevic MD (2015) Production of activated carbon derived from waste hemp (Cannabis sativa) fibers and its performance in pesticide adsorption. Microporous Mesoporous Mater 214:156-165. https://doi.org/10.1016/j. micromeso.2015.05.012

50. Jusoh A, Hartini WJH, Ali N, Endut A (2011) Study on the removal of pesticide in agricultural run off by granular activated carbon. Bioresour Technol 102(9):5312-5318. https://doi.org/10.1016/j.biortech.2010.12.074
51. Moussavi G, Hosseini H, Alahabadi A (2013) The investigation of diazinon pesticide removal from contaminated water by adsorption onto $\mathrm{NH}_{4} \mathrm{Cl}$ induced activated carbon. Chem Eng J 214:172-179. https://doi.org/10.101 6/j.cej.2012.10.034

52. Khoshnood M, Azizian S (2012) Adsorption of 2,4-dichlorophenoxyacetic acid pesticide by graphitic carbon nanostructures prepared from biomasses. J Ind Eng Chem 18(5):1796-1800. https://doi.org/10.1016/j.jiec.2012.04.007

53. Wang X, Wang H, Lu M, Teng R, Du X (2017) Facile synthesis of phenylmodified magnetic graphene/mesoporous silica with hierarchical bridgepore structure for efficient adsorption of pesticides. Mater Chem Phys 198: 393-400. https://doi.org/10.1016/j.matchemphys.2016.12.017

54. Pinto MCE, Gonçalves RGL, dos Santos RMM, Araújo EA, Perotti GF, Macedo R d, Bizeto A, Constantino VRL, Pinto FG, Tronto J (2016) Mesoporous carbon derived from a biopolymer and a clay: preparation, characterization and application for an organochlorine pesticide adsorption. Microporous Mesoporous Mater 225:342-354

55. Wanjeri WWO, Sheppard CJ, Prinsloo ARE, Ngilaa JC, Ndungua PG (2018) Isotherm and kinetic investigations on the adsorption of organophosphorus pesticides on graphene oxide based silica coated magnetic nanoparticles functionalized with 2-phenylethylamine. J Environ Chem Eng 6(1):13331346. https://doi.org/10.1016/j.jece.2018.01.064

56. Gámiz B, Hermosín MC, Cornejo J, Celis R (2015) Hexadimethrinemontmorillonite nanocomposite: characterizationand application as a pesticide adsorbent. Appl Surf Sci 332:606-613. https://doi.org/10.1016/j.a psusc.2015.01.179

57. Khairy M, Ayoub HA, Rashwan FA, Abdel-Hafez HF (2018) Chemical modification of commercial kaolin for mitigation of organic pollutants in environment via adsorption and generation of inorganic pesticides. Appl Clay Sci 153:124-133. https://doi.org/10.1016/j.clay.2017.12.014

58. Chaara D, Bruna F, Ulibarri MA, Draoui K, Barriga C, Pavlovic I (2011) Organo/ layered double hydroxide nanohybrids used to remove non ionic pesticides. J Hazard Mater 196:350-359. https://doi.org/10.1016/j.jhazmat.2 011.09 .034

59. Shattar SFA, Zakaria NA, Foo KY (2017) Utilization of montmorillonite as a refining solution for the treatment of ametryn, a second generation of pesticide. J Environ Chem Eng 5(4):3235-3242. https://doi.org/10.1016/j. jece.2017.06.031

60. Liu G, Li L, Xu D, Huang X, Xu X, Zheng S, Zhang Y, Lin H (2017) Metalorganic framework preparation using magnetic grapheneoxide- betacyclodextrin for neonicotinoid pesticide adsorption and removal. Carbohydr Polym 175:584-591. https://doi.org/10.1016/j.carbpol.2017.06.074

61. Jin R, Ji F, Lin H, Luo C, Hu Y, Deng C, Cao X, Tong C, Song G (2018) The synthesis of $\mathrm{Zr}$-metal-organic framework functionalized magneticgraphene nanocomposites as an adsorbent for fast determination of multi-pesticide residues in tobacco samples. J Chromatogr A 1577:1-7. https://doi.org/10.1 016/j.chroma.2018.09.041

62. Dehghani MH, Kamalian S, Shayeghi M, Yousefi M, Heidarinejad Z, Agarwal S, Gupta VK (2019) High-performance removal of diazinon pesticide from water using multiwalled carbon nanotubes. Microchem J 145:486-491. https://doi.org/10.1016/j.microc.2018.10.053

63. Shankar A, Kongot M, Saini VK, Kumar A (2018) Removal of pentachlorophenol pesticide from aqueous solutions using modified chitosan. Arab J Chem 13(1):1821-1830. https://doi.org/10.1016/j.arabjc.2018. 01.016

64. Tavakkoli H, Yazdanbakhsh M (2013) Fabrication of two perovskite-type oxide nanoparticles as the new adsorbents in efficient removal of a pesticide from aqueous solutions: kinetic, thermodynamic, and adsorption studies. Microporous Mesoporous Mater 176:86-94. https://doi.org/10.1016/j. micromeso.2013.03.043

65. Zhang P, Sun H, Yu L, Sun T (2013) Adsorption and catalytic hydrolysis of carbaryl and atrazine on pig manure-derived biochars: impact of structural properties of biochars. J Hazard Mater 244-245:217-224. https://doi.org/10.1 016/j.jhazmat.2012.11.046

66. Armaghan M, Amini MM (2017) Adsorption of diazinon and fenitrothion on nanocrystalline magnesium oxides. Arab J Chem 10(1):91-99. https://doi. org/10.1016/j.arabjc.2014.01.002

67. Belaroui LS, Ouali A, Bengueddach A, Galindo AL, Peña A (2018) Adsorption of linuron by an Algerian palygorskite modified with magnetic iron. Appl Clay Sci 164:26-33. https://doi.org/10.1016/j.clay.2018.03.021

68. Garba ZN, Zhou W, Lawan I, Zhang M, Yuan Z (2019) Enhanced removal of prometryn using copper modified microcrystalline cellulose (Cu-MCC): 
optimization, isotherm, kinetics and regeneration studies. Cellulose 26(10): 6241-6258. https://doi.org/10.1007/s10570-019-02531-9

69. Bansal RC, Goyal M (2005) Activated carbon adsorption. Taylor \& Francis Group, LLC, Boca Raton, pp 1-470

70. Kazmierczak-Razna J, Gralak-Podemska B, Nowicki P, Pietrzak R (2015) The use of microwave radiation for obtaining activated carbons from sawdust and their potential application in removal of $\mathrm{NO}_{2}$ and $\mathrm{H}_{2} \mathrm{~S}$. Chem Eng J 269: 352-358. https://doi.org/10.1016/j.cej.2015.01.057

71. María LS, Moure A, Domínguez H, Parajó JC (2011) Recovery, concentration and purification of phenolic compounds by adsorption: a review. J Food Eng 105:1-27

72. Xiao W, Garba ZN, Sun S, Lawan I, Wang L, Lin M, Yuan Z (2020) Preparation and evaluation of an effective activated carbon from white sugar for the adsorption of rhodamine B dye. J Clean Prod 253:119989. https://doi.org/1 0.1016/j.jclepro.2020.119989

73. Adetokun AA, Uba S, Garba ZN (2019) Optimization of adsorption of metal ions from a ternary aqueous solution with activated carbon from Acacia senegal (L.) Willd pods using Central Composite Design. J King Saud Univ Sci 31:1452-1462. https://doi.org/10.1016/j.jksus.2018.12.007

74. Garba ZN, Afidah AR (2014) Process optimization of $\mathrm{K}_{2} \mathrm{C}_{2} \mathrm{O}_{4}$-activated carbon from Prosopis africana seed hulls using response surface methodology. J Anal Appl Pyrolysis 107:306-312. https://doi.org/10.1016/j. jaap.2014.03.016

75. Garba ZN, Afidah AR (2016) Evaluation of optimal activated carbon from an agricultural waste for the removal of para-chlorophenol and 2,4dichlorophenol. Proc Saf Environ Prot 102:54-63. https://doi.org/10.1016/j. psep.2016.02.006

76. Garba ZN, Hussin MH, Galadima A, Lawan I (2019) Potentials of Canarium schweinfurthii seed shell as a novel precursor for $\mathrm{CH}_{3} \mathrm{COOK}$ activated carbon: statistical optimization, equilibrium and kinetic studies. Appl Water Sci 9(31):1-13

77. Afidah AR, Garba ZN (2016) Efficient adsorption of 4-Chloroguiacol from aqueous solution using optimal activated carbon: equilibrium isotherms and kinetics modeling. J Assoc Arab Univ Basic Appl Sci 21:17-23

78. Agarry SE, Ogunleye OO, Ajani OA (2015) Biosorptive removal of cadmium (II) ions from aqueous solution by chemically modified onion skin: batch equilibrium, kinetic and thermodynamic studies. Chem Eng Commun 202(5):655-673. https://doi.org/10.1080/0098644 5.2013 .863187

79. Kalderis D, Kayan B, Akay S, Kulaksız E, Gözmen B (2017) Adsorption of 2,4dichlorophenol on paper sludge/wheat husk biochar: process optimization and comparison with biochars prepared from wood chips, sewage sludge and hog fuel/demolition waste. J Environ Chem Eng 5(3):2222-2231. https://doi.org/10.1016/j.jece.2017.04.039

80. Garba ZN, Afidah AR, Hamza SA (2014) Potential of borassus aethiopum shells as precursor for activated carbon preparation by physico-chemical activation; optimization, equilibrium and kinetic studies. J Environ Chem Eng 2(3):1423-1433. https://doi.org/10.1016/j.jece.2014.07.010

81. Garba ZN, Shikin FBS, Afidah AR (2015) Valuation of activated carbon from waste tea for the removal of a basic dye from aqueous solution. J Chem Eng Chem Res 2:623-633

82. Garba ZN, Ugbaga NI, Amina KA (2016) Evaluation of optimum adsorption conditions for $\mathrm{Ni}$ (II) and Cd (II) removal from aqueous solution by modified plantain peels (MPP). Beni-Suef Univ J Basic Appl Sci 5(2):170-179. https:// doi.org/10.1016/j.bjbas.2016.03.001

83. Garba ZN, Zhou W, Lawan I, Xiao W, Zhang M, Wang L, Chen L, Yuan Z (2019) An overview of chlorophenols as contaminants and their removal from wastewater by adsorption: a review. J Environ Manag 241:59-75. https://doi.org/10.1016/j.jenvman.2019.04.004

84. Ali I, Asim M, Khan TA (2012) Low cost adsorbents for the removal of organic pollutants from wastewater. J Environ Manag 113:170-183. https:// doi.org/10.1016/j.jenvman.2012.08.028

85. Nasehi SM, Ansari S, Sarshar M (2012) Removal of dark colored compounds from date syrup using activated carbon: a kinetic study. J Food Eng 111(3): 490-495. https://doi.org/10.1016/j.jfoodeng.2012.02.037

86. Chen W-S, Lin C-W, Chang F-C, Lee W-J, Wu J-L (2012) Utilization of spent activated carbon to enhance the combustion efficiency of organic sludge derived fuel. Bioresour Technol 113:73-77. https://doi.org/10.1016/j. biortech.2011.12.026

87. Darweesh TM, Ahmed MJ (2017) Adsorption of ciprofloxacin and norfloxacin from aqueous solution onto granular activated carbon in fixed bed column. Ecotoxicol Environ Saf 138:139-145. https://doi.org/10.1016/j. ecoenv.2016.12.032

88. Delgado LF, Charles P, Glucina K, Morlay C (2012) The removal of endocrine disrupting compounds, pharmaceutically activated compounds and cyanobacterial toxins during drinking water preparation using activated carbon-a review. Sci Total Environ 435-436:509-525. https://doi.org/10.1016/ j.scitotenv.2012.07.046

89. Ayranci E, Hoda N (2005) Adsorption kinetics and isotherms of pesticides onto activated carbon-cloth. Chemosphere 60(11):1600-1607. https://doi. org/10.1016/j.chemosphere.2005.02.040

90. Memon GZ, Bhanger MI, Akhtar M, Talpur FN, Memon JR (2008) Adsorption of methyl parathion pesticide from water using watermelon peels as a low cost adsorbent. Chem Eng J 138(1-3):616-621. https://doi.org/10.1016/j.cej.2 007.09.027

91. Cobas M, Meijide J, Sanromán MA, Pazos M (2016) Chestnut shells to mitigate pesticide contamination. J Taiwan Inst Chem Eng 61:166-173. https://doi.org/10.1016/j.jtice.2015.11.026

92. Aia L, Zhang C, Liao F, Wang Y, Li M, Meng L, Jiang J (2011) Removal of methylene blue from aqueous solution with magnetite loaded multi-wall carbon nanotube: kinetic, isotherm and mechanism analysis. J Hazard Mater 198:282-290. https://doi.org/10.1016/j.jhazmat.2011.10.041

93. Crini G (2006) Non-conventional low-cost adsorbents for dye removal: a review. Bioresour Technol 97(9):1061-1085. https://doi.org/10.1016/j. biortech.2005.05.001

94. Acosta R, Fierro V, Yuso AM, Nabarlatz D, Celzard A (2016) Tetracycline adsorption onto activated carbons produced by $\mathrm{KOH}$ activation of tyre pyrolysis char. Chemosphere 149:168-176. https://doi.org/10.1016/j. chemosphere.2016.01.093

95. Jawad AH, Mamat NFH, Abdullah MF, Ismail K (2017) Adsorption of methylene blue onto acid-treated Mango peels: kinetic, equilibrium and thermodynamic. Desalin Water Treat 59:210-219. https://doi.org/10.5004/ dwt.2017.0097

96. Behloul M, Lounici H, Abdi N, Drouiche N, Mameri N (2017) Adsorption study of metribuzin pesticide on fungus Pleurotus mutilus. Int J Biol Macromol 119:687-695

97. Chen X, Zhou Q, Liu F, Peng Q, Teng P (2019) Removal of nine pesticide residues from water and soil by biosorption coupled with degradation on biosorbent immobilized laccase. Chemosphere 233:49-56. https://doi.org/1 0.1016/j.chemosphere.2019.05.144

98. Taha SM, Amer ME, Elmarsafy AE, Elkady MY (2014) Adsorption of 15 different pesticides on untreated and phosphoric acid treated biochar and charcoal from water. J Environ Chem Eng 2(4):2013-2025. https://doi.org/1 0.1016/j.jece.2014.09.001

99. Kumar M, Philip L (2006) Adsorption and desorption characteristics of hydrophobic pesticide endosulfan in four Indian soils. Chemosphere 62(7): 1064-1077. https://doi.org/10.1016/j.chemosphere.2005.05.009

100. Otero R, Fernández JM, Ulibarri MA, Celis R, Bruna F (2012) Adsorption of non-ionic pesticide S-Metolachlor on layered double hydroxides intercalated with dodecylsulfate and tetradecanedioate anions. Appl Clay Sci 65-66:72-79

101. Rodríguez-Liébana JA, López-Galindo A, Jiménez de Cisneros C, Gálvez A, Rozalén M, Sánchez-Espejo R, Caballero E, Peña A (2016) Adsorption/ desorption of fungicides in natural clays from Southeastern Spain. Appl Clay Sci 132-133:402-411

102. Jevremović $A$, Bober $P$, Mičušík M, Kuliček J, Acharya U, Pfleger J, MilojevićRakić M, Krajišnik D, Trchová M, Stejskal J, Ćirić-Marjanović G (2019) Synthesis and characterization of polyaniline/BEA zeolite composites and their application in nicosulfuron adsorption. Microporous Mesoporous Mater 287:234-245. https://doi.org/10.1016/j.micromeso.2019.06.006

103. Milojević-Rakić M, Janošević A, Krstić J, Nedić Vasiljević B, Dondur V, CiricMarjanovic G, Ciric-Marjanovic G, Ciric-Marjanovic G, Ciric-Marjanovic G (2013) Polyaniline and its composites with zeolite ZSM-5 for efficient removal of glyphosate from aqueous solution. Microporous Mesoporous Mater 180:141-155. https://doi.org/10.1016/j.micromeso.2013.06.025

104. Jović A, Milikić J, Bajuk-Bogdanović D, Milojević-Rakić M, Vasiljević BN, Krstić J, Cvjetićanin N, Šljukić B (2018) 12-phosphotungstic acid supported on BEA zeolite composite with carbonized polyaniline for electroanalytical sensing of phenols in environmental samples. J Electrochem Soc 165(16):H1013H1020. https://doi.org/10.1149/2.0021816jes

105. Milojević-Rakić M, Bajuk-Bogdanović D, Nedić Vasiljević B, Rakić A, Škrivanj S, Ignjatović L, Dondur V, Mentus S, Cirić-Marjanović G (2018) 
Polyaniline/FeZSM-5 composites - synthesis, characterization and their high catalytic activity for the oxidative degradation of herbicide glyphosate. Microporous Mesoporous Mater 267:68-79. https://doi.org/1 0.1016/j.micromeso.2018.03.019

106. Bajuk-Bogdanović D, Jović A, Vasiljević BN, Milojević-Rakić M, Kragović M, Krajišnik D, Holclajtner-Antunović I, Dondur V (2017) 12-

Tungstophosphoric acid/BEA zeolite composites - characterization and application for pesticide removal. Mater Sci Eng B 225:60-67. https:// doi.org/10.1016/j.mseb.2017.08.011

107. Yang Q, Wang J, Zhang W, Liu F, Yue X, Liu Y, Yang M, Li Z, Wang J (2017) Interface engineering of metal organic framework on graphene oxide with enhanced adsorption capacity for organophosphorus pesticide. Chem Eng J 313:19-26. https://doi.org/10.1016/j.cej.2016.12.041

108. Elhussein EAA, Şahin S, Bayazit SS (2018) Preparation of $\mathrm{CeO}_{2}$ nanofibers derived from Ce-BTC metal-organic frameworks and its application on pesticide adsorption. J Mol Liq 255:10-17. https://doi.org/10.1016/j.molliq.2 018.01.165

109. Denton P, Rostron C (2013) Pharmaceutics: the science of medicine design. Oxford University Press, Oxford

110. Crini G, Badot P-M (2008) Application of chitosan, a natural aminopolysaccharide, for dye removal from aqueous solutions by adsorption processes using batch studies: a review of recent literature. Prog Polym Sci 33(4):399-447. https://doi.org/10.1016/j.progpolymsci.2007.11.001

111. Febrianto J, Kosasih AN, Sunarso J, Ju Y-H, Indraswati N, Ismadji S (2009) Equilibrium and kinetic studies in adsorption of heavy metals using biosorbent: a summary of recent studies. J Hazard Mater 162(2-3):616-645 https://doi.org/10.1016/j.jhazmat.2008.06.042

112. Park D, Yun Y-S, Park JM (2010) The past, present, and future trends of biosorption. Biotechnol Bioprocess Eng 15(1):86-102. https://doi.org/10.1 007/s12257-009-0199-4

113. Babel S, Kurniawan TA (2003) Low-cost adsorbents for heavy metals uptake from contaminated water: a review. J Hazard Mater 97(1):219-243. https:// doi.org/10.1016/50304-3894(02)00263-7

114. Shawabkeh RA, Tutunji MF (2003) Experimental study and modeling of basic dye sorption by diatomaceous clay. Appl Clay Sci 24(1-2):111-120. https://doi.org/10.1016/S0169-1317(03)00154-6

115. Xu G, Yang X, Spinosa L (2015) Development of sludge-based adsorbents: preparation, characterization, utilization and its feasibility assessment. J Environ Manag 151:221-232. https://doi.org/10.1016/j.jenvman.2014.08.001

116. Gupta VK, Suhas PJM (2009) Application of low-cost adsorbents for dye removal-a review. J Environ Manag 90(8):2313-2342. https://doi.org/10.101 6/j.jenvman.2008.11.017

117. Mohan D, Pittman CU Jr (2006) Activated carbons and low cost adsorbents for remediation of tri- and hexavalent chromium from water. J Hazard Mater 137(2):762-811. https://doi.org/10.1016/j.jhazmat.2006.06.060

118. Zhou Y, Lu J, Zhou Y, Liu Y (2019) Recent advances for dyes removal using novel adsorbents: a review. Environ Pollut 252(Pt A):352-365. https://doi. org/10.1016/.jenvpol.2019.05.072

119. Devi P, Saroha AK (2017) Utilization of sludge based adsorbents for the removal of various pollutants: a review. Sci Total Environ 578:16-33. https:// doi.org/10.1016/j.scitotenv.2016.10.220

\section{Publisher's Note}

Springer Nature remains neutral with regard to jurisdictional claims in published maps and institutional affiliations.

\section{Submit your manuscript to a SpringerOpen ${ }^{\circ}$ journal and benefit from:}

- Convenient online submission

- Rigorous peer review

- Open access: articles freely available online

- High visibility within the field

- Retaining the copyright to your article

Submit your next manuscript at $\boldsymbol{\nabla}$ springeropen.com 